\title{
The Principal Purpose Test in the Multilateral Convention: An in-depth Analysis
}

\author{
Vikram Chand*
}

\begin{abstract}
It is estimated that the Principal Purpose Test (PPT) contained in the Multilateral Instrument (MLI) will be incorporated in almost one thousand one bundred tax treaties. There is no doubt that this test will have wide ramifications for structuring activities that are carried out with tax treaties. In this contribution the author undertakes a detailed analysis of the test. Firstly, the author discusses the background to the PPT. Secondly, the author analyses various elements of the test and provides guidance on interpreting its subjective and objective elements. Thirdly, the author critically comments and expresses his opinion on all the nineteen examples that have been provided in the commentary in relation to the test. In this regard, it is pertinent to note that several of these examples seem to be inspired from Court judgments on the 'beneficial ownership' clause and the Exchange of Letters with respect to the anti-conduit rule contained in the US-UK tax treaty. Fourthly, the author analyses the legal consequences of denying treaty benefits in relation to rule and treaty shopping schemes by focussing on the discretionary relief clause. Finally, the autbor concludes and provides certain recommendations to intermediary entities such as holding, financing and intellectual property (IP) entities. It is pertinent to note that the author will analyse the relationship between the PPT (as well as the guiding principle) and other anti-avoidance rules, treaty and domestic, in a subsequent contribution.
\end{abstract}

\section{INTRODUCTION}

1. The OECD released the Multilateral Convention to swiftly implement the various tax treaty related Base Erosion and Profit Shifting (BEPS) measures (Multilateral Instrument or MLI) ${ }^{1}$ and its Explanatory Statement ${ }^{2}$ in November 2016. The MLI ${ }^{3}$ contains the text of the various tax treaty related changes that were proposed by Action 2 (hybrid mismatches), ${ }^{4}$ Action 6 (treaty abuse), ${ }^{5}$ Action 7 (artificial avoidance of the PE status) $)^{6}$ and Action 14 (improving dispute resolution) $)^{7}$ of the BEPS Plan whereas the Explanatory Statement clarifies the text of the Convention. ${ }^{8}$
2. With respect to countering treaty abuse, Action 6 of the BEPS Plan had recommended a minimum standard that States could adopt into their tax treaty network. ${ }^{9}$ Specifically, it was suggested that States should, firstly, change the preamble of the tax treaties. ${ }^{10}$ In this regard, Article 6(1) of the MLI provides that the preamble of the Covered Tax Agreement (CTA) shall be modified. This change ensures that the purpose of tax treaties, in addition to eliminating double taxation, is not to create opportunities for tax evasion or tax avoidance (especially, treaty-shopping arrangements). ${ }^{11}$

\section{Notes}

$\mathrm{PhD}$ and LLM (International tax Law); Executive Director - International Tax Education (Masters of Advanced Studies in International Taxation and Executive Program in Transfer Pricing), Tax Policy Center of the University of Lausanne, Switzerland. Email: vikram.chand@unil.ch. The author would like to thank Mr Quentin Oyon and Mr Benjamin Malek (researchers at the Tax Policy Center) for their assistance with respect to this article.

2016 OECD, Multilateral Convention.

2016 OECD, Explanatory Statement to the Multilateral Convention.

For an analysis of the structure and functioning of the MLI and/or its provisions see for instance: Bosman, MLI; Danon, Salome, MLI; Baker, MLI; Hattingh, MLI; and Butani, MLI.

2015 OECD, Final Report on Hybrid Mismatches.

2015 OECD, Final Report on Treaty Abuse.

2015 OECD, Final Report on Permanent Establishments.

2015 OECD, Final Report on Dispute Resolution.

2016 OECD, Explanatory Statement to the Multilateral Convention, para. 11

2015 OECD, Final Report on Treaty Abuse, paras 22-23.

10 Ibid. paras $72-74$.

11 See 2016 OECD, Multilateral Convention, Art. 6(1). Also see 2015 OECD, Final Report on Treaty Abuse, paras 72-74. Also see 2017 OECD Model (draft), Title and Preamble. 
3. Secondly, in addition to changing the preamble, States were required to add to their tax treaties either:

(1) the Principal Purpose Test (PPT) only ${ }^{12}$ (Article 7 (1) of the MLI);

(2) the PPT and the limitation of benefit (LOB) clause $^{13}$ (the simplified version, ${ }^{14}$ which is reflected in Article 7(8)-Article 7(13) of the MLI);

(3) Detailed LOB clause and anti-abuse measures to counteract conduit financing. ${ }^{15}$ The anti-abuse measures could stem from domestic law (such as the US conduit financing rules ${ }^{16}$ ) or could be treaty based (such as the anti-conduit rule contained in Article 3 (1)(n) of the 2001 US-UK tax treaty ${ }^{17}$ ).

4. In order to meet this minimum standard, seventy-one signatory countries to the MLI (as on 17 August 2017) ${ }^{18}$ have adopted the revised preamble and the PPT. ${ }^{19} \mathrm{~A}$ few States, in addition to the revised preamble and the PPT, have also made their choice to opt for the simplified LOB clause with respect to their CTAs. ${ }^{20}$

5. The purpose of this article is to analyse the PPT contained in the MLI as it is estimated that this rule will be incorporated in more than 1,100 treaties. $^{21}$ Specifically, the author discusses the background to the test i.e. the guiding principle (see section 2); analyses the various elements of the test (see section 3); critically comments on the various examples that have been proposed in relation to the test (see section 4); analyses the legal consequences of denying treaty benefits in rule and treaty shopping situations, especially, in light of the discretionary relief clause (see section 5), concludes by summarizing his analysis (see section 6) and by providing recommendations to intermediary entities (see section 7). It is pertinent to note that the author will analyse the relationship between the PPT (as well as the guiding principle) and other anti-avoidance rules, treaty and domestic, in a subsequent contribution.

\section{Evolution OF THE TEST: THE GUIDING PRINCIPLE}

6. The OECD Commentary ${ }^{22}$ states that tax treaty benefits need not be granted to a taxpayer when that

\section{Notes}

122015 OECD, Final Report on Treaty Abuse, para. 26; 2017 OECD Model (draft), Art. 29(9)

132017 OECD Model (draft), Art. 29(1)-Art. 29(7).

142015 OECD, Final Report on Treaty Abuse, para. 25 (Commentary in para. 2); 2017 OECD Comm (Draft), Art. 29, para. 2.

152015 OECD, Final Report on Treaty Abuse, para. 25 (Commentary in para. 3); 2017 OECD Comm (Draft), Art. 29, para. 3.

16 In US tax law sphere, the use of intermediary conduit entities is counteracted by specific conduit financing regulations. These rules, which were introduced in 1993 , target foreign taxpayers that use intermediary entities to obtain reduced withholding taxes available pursuant to US tax treaties. The rules are triggered when (1) there is a 'financing arrangement' wherein two or more financing transactions are linked by an intermediary entity; (2) the participation of the intermediary entity reduces the tax imposed under the US tax law provisions; (3) the participation of the intermediary entity is pursuant to a tax avoidance plan; and (4) the intermediary entity is related to the borrower or lender or unrelated but 'would not have participated in the financing arrangement on substantially the same terms but for the fact that the financing entity bas engaged in the financing transaction with the intermediary entity'. If the rules are triggered then the US tax authorities have the power to re-characterize financing transactions made through an intermediate, as direct financing transactions. See s. 881, US IRC read in conjunction with US Treasury regulations, 1.881-3; Brauner, Beneficial Ownership, at 159-160; Ringler, Beneficial Ownership, at 212-218.

17 The provision provides that the term 'conduit arrangement means a transaction or series of transactions: (i) which is structured in such a way that a resident of a Contracting State entitled to the benefits of this Convention receives an item of income arising in the other Contracting State but that resident pays, directly or indirectly, all or substantially all of that income (at any time or in any form) to another person who is not a resident of either Contracting State and who, if it received that item of income direct from the other Contracting State, would not be entitled under a convention for the avoidance of double taxation between the state in which that other person is resident and the Contracting State in which the income arises, or otherwise, to benefits with respect to that item of income which are equivalent to, or more favourable than, those available under this Convention to a resident of a Contracting State; and (ii) which has as its main purpose, or one of its main purposes, obtaining such increased benefits as are available under this Convention'. See Art. 3(1)(n), UK-US Tax Treaty (2001). The provision provides for an objective and motive test. Similar provision is found in Art. 3(1)(L), UK-Swiss Tax Treaty (1977 as amended by the 2009 protocol). In its 2014 report on treaty abuse, the OECD had recommended States to adopt such provisions in their tax treaty network. See 2014 OECD, Report on Treaty Abuse, para. 17 (Commentary in para. 15). However, this provision was not reflected in its final report on treaty abuse as issues were identified with respect to the phrase 'all or substantially all of that income'. See Ringler, Beneficial Ownership, at 348-350.

18 See http://www.oecd.org/tax/treaties/beps-mli-signatories-and-parties.pdf.

19 The following countries have adopted the PPT as a minimum standard: Andorra, Argentina, Armenia, Australia, Austria, Belgium, Bulgaria, China, Costa Rica, Croatia, Cyprus, Czech Republic, Denmark, Egypt, Fiji, Finland, France, Gabon, Georgia, Germany, Greece, Guernsey, Hong Kong, Hungary, Iceland, India, Indonesia, Ireland, Isle of Man, Israel, Italy, Japan, Jersey, Korea, Liechtenstein, Lithuania, Luxembourg, Malta, Mexico, Netherlands, New Zealand, Pakistan, Portugal, Romania, Russia, San Marino, Singapore, Slovak Republic, Slovenia, South Africa, Spain, Sweden, Switzerland, Turkey, United Kingdom, Uruguay, Cameroon and Nigeria. Moreover, the following countries have opted to apply the PPT as an interim measure which means that, in the near future, these States may either adopt the LOB clause as a replacement or in addition to the PPT: Canada, Chile, Colombia, Kuwait, Poland, Senegal, Serbia, Seychelles and Mauritius.

20 See the positions adopted by Argentina, Armenia, Bulgaria, Chile, Colombia, Denmark, Iceland, India, Indonesia, Mexico, Russia, Slovak Republic and Uruguay.

21 See MLI, Information Brochure, https://www.oecd.org/tax/treaties/multilateral-instrument-BEPS-tax-treaty-information-brochure.pdf.

22 The extent to which the OECD Commentary can be used in the interpretation of tax treaties has been the subject matter of extensive debate and there seems to be no consensus regarding its legal status. Specifically, the issue arises as regards the relationship between the interpretation rules of the Vienna Convention (VCLT) and the OECD Commentary i.e. is the practice of considering the OECD Commentary permitted by the rules of the VCLT? In the author's view, the attempt to classify the OECD Commentary under one provision or another of the VCLT is not a gainful exercise. This is because the interpretation provisions contained in the VCLT are a 'means to an end and not as an end in themselves'. The draft Commentary to the VCLT makes this clear and states that the drafters, in drafting the interpretation rules of the VCLT, never intended Art. 31 and Art. 32 of the VCLT to be a complete codification of all principles and maxims that has to be adopted in interpreting treaties. Therefore, even if the OECD Commentary cannot be considered to fit in Art. 31 and Art. 32 VCLT - it is submitted that it should be considered relevant in the tax treaty interpretation process 
taxpayer's arrangement or transaction is abusive. Towards this end, the 2003 OECD Commentary, in paragraph 9.5, provides for a 'guiding principle 23 which can be used to determine if abuse exists or does not exist. Abuse arises when:

(1) a main purpose for entering into a transaction or arrangement was to secure a more favourable tax position (subjective element); and

(2) obtaining that more favourable tax position would be contrary to the object and purpose of the relevant tax treaty provisions (objective element).

7. These elements are also found in judicial doctrines and domestic statutory General AntiAvoidance Rules (GAARs) of several States. ${ }^{24}$ In light of these similarities, in the author's opinion, the guiding principle can be regarded as a treaty GAAR. ${ }^{25}$ This is confirmed by the report on BEPS Action $6^{26}$ and the 2017 draft OECD commentary. ${ }^{27}$ Accordingly, if the relevant tax treaty does not incorporate the PPT, the guiding principle could be applied to deny treaty benefits. Of course, denial of treaty benefits will depend on whether or not all the elements of the principle are satisfied. Further, the author's opinion is that the guiding principle can be applied to a tax treaty that has been concluded only after January $2003^{28}$ (as it was introduced only in that year). Moreover, the principle can be applied only to fact patterns that are not caught by other treaty anti-avoidance rules. ${ }^{29}$ This being said, the author states that Courts, even though they have referred to the 2003 OECD Commentary in abusive cases, ${ }^{30}$ have not discussed or commented on the guiding principle till date.

\section{The PPT AND AN ANALYSIS OF ITS ELEMENTS}

\section{I Preliminary Remarks}

8. The elements contained in the guiding principle are also reflected in the PPT. In fact the PPT is built on the guiding principle. ${ }^{31}$ Article $7(1)$ of the $\mathrm{MLI}^{32}$ provides that:

Notwithstanding any provisions of a Covered Tax Agreement,

a) a benefit under the Covered Tax Agreement shall not be granted in respect of an item of income or capital (the presence of a benefit)

b) if it is reasonable to conclude, having regard to all relevant facts and circumstances, that obtaining that benefit was one of the principal purposes ${ }^{33}$ of any arrangement or transaction that resulted directly or indirectly in that benefit (subjective element)

c) unless it is established that granting that benefit in these circumstances would be in accordance with the object and

\section{Notes}

because Art. 31 and Art. 32 VCLT 'were never intended to be exhaustive either in the description of materials that could be examined by, or the principles of interpretation that could be followed' in interpretation of an international treaty. Therefore, the author's position is that the OECD Commentary, existing at the time of conclusion of a tax treaty, is not a legally binding instrument but nevertheless plays an important role in the tax treaty interpretation process. Moreover, the author states that subsequent versions of the OECD Commentary can be considered, only if, the revised Commentary is in the nature of a clarification. Consequently, if the revised Commentary represents a fundamental change or if the Commentary reverses or contradicts previous versions then that Commentary should be disregarded and should not be taken into the tax treaty interpretation process. See Chand, Thesis, Ch. 6.

232003 OECD Comm. Art. 1, para. 9.5; 2015 OECD, Final Report on Treaty Abuse, para. 59 (Commentary in para. 14); 2017 OECD Comm (Draft), Art. 1, para. 61.

24 See Chand, Thesis, Ch. 3. In this chapter, the author provides a comparative overview of the judicial doctrines, statutory GAARs or SAARs that are applied by the source or residence States to counteract cross-border tax avoidance schemes.

25 See Chand, Thesis, s. 9.3; Arnold \& Van Weeghel, Abuse, at 93; Arnold, 2003 changes, at 250. The author does not agree with the position that the guiding principle acts as a restriction to the application of domestic anti-avoidance rules (that are used to counter treaty abuse) as those rules, in general, conflict with tax treaties and hence should not be applied. See Chand, Thesis, s. 9.3. Moreover, the guiding principle cannot act as a restriction to the inherent anti-abuse rule doctrine as that rule does not exist. See Chand, Thesis, s. 21.3.1.1. These issues will be discussed in a subsequent contribution by the author in the same journal.

262015 OECD, Final Report on Treaty Abuse, para. 59 (Commentary in para. 14).

272017 OECD Comm (Draft), Art. 1, para. 61; 2017 OECD Comm (Draft), Art. 29, para. 169.

28 See Chand, Thesis, s. 9.1.

29 See Chand, Thesis, s. 21.3.3. The relationship between the guiding principle and treaty anti-avoidance rules will be discussed in a subsequent contribution by the author in the same journal.

30 For instance, see the decision of the Swiss Supreme Court in A Holding ApS v. Federal Tax Administration, 8 ITLR 536, 28 Nov. 2005 , at 536-562.

312015 OECD, Final Report on Treaty Abuse, para. 26 (Commentary in para. 1); See De Broe, EU Law, at 209.

322016 OECD, Multilateral Convention, Art. 7(1)

33 Similar language is used in EU Direct Tax Directives. For instance, Art. 11(1)(a) of the Merger Directive (MD) provides that the benefits of the directive are not available when the transaction (merger, division, transfer of assets or exchange of shares) 'bas as its principal objective or as one of its principal objectives tax evasion or tax avoidance'. See EU MD, Directive 90/ 434/EEC, Art. 11(a). Likewise, Art. 1(2) of the Parent-Subsidiary Directive (PSD), as amended in Jan. 2015, provides that 'Member States shall not grant the benefits of this Directive to an arrangement or a series of arrangements which, having been put into place for the main purpose or one of the main purposes of obtaining a tax advantage that defeats the object or purpose of this Directive, are not genuine having regard to all relevant facts and circumstances'. See EU PSD, Directive 2015/121, Art. 1(2). Moreover, the recent EU Anti-Tax Avoidance Directive proposes Member States to incorporate a GAAR in their domestic law vis-à-vis corporate taxation. Art. 6(1) of the directive states 'For the purposes of calculating the corporate tax liability, a Member State shall ignore an arrangement or a series of arrangements which, having been put into place for the main purpose or one of the main purposes of obtaining a tax advantage that defeats the object or purpose of the applicable tax law, are not genuine having regard to all relevant facts and circumstances. An arrangement may comprise more than one step or part'. See EU ATAD, Directive 2016/1164, Art. 6(1). Moreover, see fn. 61 (infra). 
purpose of the relevant provisions of the Covered Tax Agreement (objective element).

9. Article 7(2), ${ }^{34}$ the compatibility clause, provides that such a provision shall be included in place of or in the absence of ${ }^{35}$ similar provisions of all CTAs. However, pursuant to Article 7(15), ${ }^{36}$ the reservation clause, a Party may opt out from the application of the PPT rule when (1) that Party, pursuant to Article $7(15)(a)$, intends to meet the minimum standard by adopting a detailed LOB provision and either rules to address conduit financing or a PPT rule through bilateral discussions with its treaty partner; or (2) when the CTA, pursuant to Article 7(15)(b), already contains a rule similar to the PPT rule. ${ }^{37}$

\subsection{Burden of Proof}

10. There is no doubt that the burden of proof ${ }^{38}$ of the PPT is unbalanced and unreasonable ${ }^{39}$ in comparison to the guiding principle. ${ }^{40}$ Even though the tax authorities will be required to undertake an objective analysis of the facts of the transaction they only have to 'reasonably" (and not convincingly) conclude that the subjective element is satisfied. ${ }^{42}$ This threshold seems to be low in comparison to the burden assumed by the taxpayer wherein it is required to 'establish' (convincingly) that granting the benefit is in accordance with the object and purpose of the relevant provisions of the tax treaty (objective element). ${ }^{43}$ This would typically be the case in regular tax assessments.

11. The existence of a benefit (see section 3.3) and proving that one of the principal purposes of the arrangement is to secure that benefit (see section 3.4) requires an objective factual analysis. If the case goes for litigation before the Courts, as a starting point the tax authorities will have to prove that a tax benefit exists and a principal purpose of the transaction/ arrangement was to obtain that benefit. The taxpayer should then be given an opportunity to refute or challenge the tax authorities claims by disputing the existence of a benefit or showing that the transaction was driven by non-tax purposes. When the Court reasonably concludes that the benefit is available and the subjective element is satisfied, the taxpayer should be given the opportunity to demonstrate that he acts in accordance with the objective element (see section 3.5). The tax authorities should then be given an opportunity to refute or challenge the taxpayer's claims. In the end, based on an objective analysis of the facts, the Court will have to decide whether or not the transaction/arrangement satisfied the PPT. If the existence of 'abuse', 'tax avoidance' or 'artificial nature of the arrangement' is not clear to the Court, then the benefit of the doubt, in the author's opinion, shall go to the taxpayer. ${ }^{44}$

\subsection{Benefit Under the Tax Treaty with Respect to an Arrangement or Transaction}

12. The PPT provides that a 'benefit', with respect to an 'arrangement'/'transaction', 45 under the tax treaty, whether available directly or indirectly, ${ }^{46}$ should not be given if the subjective and objective

\section{Notes}

342016 OECD, Multilateral Convention, Art. 7(2).

35 This implies that the provision will apply in all cases. See 2016 OECD, Explanatory Statement to the Multilateral Convention, para. 15.

362016 OECD, Multilateral Convention, Art. 7(15).

372016 OECD, Explanatory Statement to the Multilateral Convention, para. 85

38 There is scholarly discussion that the burden of proof is disproportionate from an EU Law perspective. See De Broe, EU Law, at 238-239.

39 De Broe \& Luts, BEPS, at 132; De Broe, EU Law, at 216; Lang, PPT rule, at 660; Chand, Thesis, s. 9.3.5.

40 With respect to the guiding principle, the author submits that the tax authorities assume the burden of proof and they have to prove that the transaction undertaken by the taxpayer satisfies the subjective and objective elements. De Broe, Thesis, at 319; De Broe \& Luts, BEPS, at 132; Chand, Thesis, s. 9.3.5.

41 There is scholarly discussion on whether or not the PPT and, in particular, the reasonableness requirement conflicts with the principle of legal certainty in EU Law. See De Broe, EU Law, at 239; Weber, PPT, s. 5; Danon \& Salome, MLI, s. 3.5.4.1.

42 De Broe \& Luts, BEPS, at 132; Lang, PPT rule, at 659; Chand, Thesis, s. 9.3.5.

432015 OECD, Final Report on Treaty Abuse, para. 26 (Commentary in para. 2); 2017 OECD Comm (Draft), Art. 29, para. 170; Chand, Thesis, s. 9.3.5.

44 See the approach of the Canadian Supreme Court to interpret the Canadian GAAR in Canada Trust Co Mortgage Co v. Canada, 2005 SCC 54, 19 Oct. 2005, para. 30; Chand, Thesis, s. 9.3.5.

45 The terms 'arrangement' or 'transaction', are to be interpreted broadly. They include 'any agreement, understanding, scheme, transaction or series of transactions, whether or not they are legally enforceable'. Specifically, they include 'transactions' or 'arrangements' with respect to (1) the creation, assignment, acquisition or transfer of the income or of the property or right in respect of which the income arises; and (2) the establishment, acquisition or maintenance of a person who derives the income, including the establishment of that person as a resident of one of the Contracting States. See 2015 OECD, Final Report on Treaty Abuse, para. 26 (Commentary in para. 9); 2017 OECD Comm (Draft), Art. 29, para. 177. These broad definitions set a low threshold for considering the possible application of the PPT. Moreover, in order to understand, the terms 'series of transactions' see Canada Trust Co Mortgage Co v. Canada, paras 23-26; Moreover, see the discussion on the step transaction doctrine applied in the US and UK. See Chand, Thesis, s. 3.2.3.

462015 OECD, Final Report on Treaty Abuse, para. 26 (Commentary in para. 8); 2017 OECD Comm (Draft), Art. 29, para. 176. 
elements are satisfied. ${ }^{47}$ The commentary to the PPT states that the term 'benefit' includes 'all limitations... on taxation imposed on the State of source under Articles 6 through 22 of the Convention, the relief from double taxation provided by Article 23, and the protection afforded to residents and nationals of a Contracting State under Article 24 or any other similar limitations. ${ }^{48}$ The issue arises as to whether a procedural benefit available to a taxpayer, such as access to a MAP or arbitration under Article 25 of the OECD Model, can be denied under the PPT? In the author's opinion, this should not be the case since such a benefit cannot be considered as 'any other similar limitations' as provided in the commentary to this rule.49 Furthermore, it should be noted that the term 'benefit' does not include the treaties scope (Articles 1-2 of the OECD Model) and definitional provisions (Articles 3-5 of the OECD Model). Arguably, these provisions by themselves do not give any benefits and therefore should be read in conjunction with the other operative provisions. ${ }^{50}$ Moreover, the author states that only benefits covered under the relevant tax treaty will fall within the scope of the PPT. Benefits arising to a taxpayer under the domestic law (direct or indirect tax related benefits) or another tax treaty or EU Law will not fall under the scope of this test. ${ }^{51}$

\subsection{The Subjective Element}

\subsection{Introductory Comments}

13. Treaty benefits will be denied under the PPT if it is reasonably concluded that 'one of the principal purposes $^{52}$ for entering into the transaction/arrangement was to obtain a tax benefit. It is obvious that the taxpayer cannot avoid the application of this element by simply stating that the arrangement or transaction was not undertaken or arranged to obtain the benefits of the Convention'. 53 Likewise, the tax authorities cannot uphold the application of this element by comparing the actual transaction with an alternative transaction that might have resulted in higher taxes. ${ }^{54}$ Therefore, in order to determine the 'purposes' for entering into the arrangement or transaction, an objective analysis of all facts and circumstances surrounding the transaction/arrangement needs to be carried out. $^{55}$

\subsubsection{Factual Analysis Indicates that Sole Purpose of the Transaction or Arrangement Is to Obtain Tax Benefits}

14. If an objective analysis of all facts and circumstances surrounding the transaction/arrangement leads to the conclusion that the principal purpose (or the main purpose or the dominant purpose or the sole purpose or the essential aim) of the transaction/ arrangement is to obtain a tax benefit, then there is no doubt that the subjective element should be satisfied $^{56}$ (refer to the fact patterns in section 4.2). Even if this is the case, the taxpayer has the opportunity to establish that the benefit is in accordance with the 'object and purpose of the relevant provisions of the Covered Tax Agreement' (see section 3.5).

\section{Notes}

47 Canada Trust Co Mortgage Co v. Canada, paras 18-20.

482014 OECD, Report on Treaty Abuse, para. 17 (Commentary in para. 7); 2015 OECD, Final Report on Treaty Abuse, para. 26 (Commentary in para. 7 ); 2017 OECD Comm (Draft), Art. 29, para. 175; Chand, Thesis, s. 9.3.2.

49 Lang, PPT rule, at 657; De Broe, EU Law, at 218-221.

50 De Broe \& Luts, BEPS, at 131; Lang, PPT rule, at 657; Chand, Thesis, s. 9.3.2.

51 Lang, PPT rule, at 656; De Broe \& Luts, BEPS, at 131; De Broe, EU Law, at 210; Chand, Thesis, s. 9.3.2.

52 Commentators contend that the subjective element could conflict with the proportionality principle in EU Law. This is because ECJ case law uses a higher threshold to determine the existence of abuse i.e. abuse arises only when the essential aim or sole aim or sole purpose of the transaction/arrangement is to obtain a tax benefit. See De Broe, EU Law, at 237-238; Moreover, see the Opinion Of Advocate General Bobek in Cussens and others, Case No: C-251/16, 7 Sept. 2017, para. 97. A commentator discusses whether this phrase is to be interpreted on a pure subjective basis (intention or motive of the taxpayer) or by taking into consideration its objective content (purpose of the arrangement). See Moreno, PPT, at 436-440. In my opinion, the subjective element represents an objective analysis test.

532015 OECD, Final Report on Treaty Abuse, para. 26 (Commentary in para. 11); 2017 OECD Comm (Draft), Art. 29, para. 179; Also see Canada Trust Co Mortgage Co v. Canada, para. 29; Chand, Thesis, s. 9.3.3.

54 Canada Trust Co Mortgage Co v. Canada, para. 30; Chand, Thesis, s. 9.3.3.

552015 OECD, Final Report on Treaty Abuse, para. 26 (Commentary in para. 10); 2017 OECD Comm (Draft), Art. 29, para. 178

56 Chand, Thesis, s. 9.3.3. In fact, the ECJ case law reaches a similar conclusion in the context of interpreting EU directives. In the context of the VAT directive, the ECJ has held that abuse arises when firstly 'the transaction concerned ... result in the accrual of a tax advantage the grant of which would be contrary to the purpose of those provisions' (objective test) and secondly 'it must also be apparent from a number of objective factors that the essential aim of the transactions concerned is to obtain a tax advantage' (subjective test). See ECJ: Halifax plc and others v. Customs and Excise Commissioners, Case No: C-255/02, 21 Feb. 2006, paras 74-75; In the context of interpreting Art. 11(a) of the Merger Directive, the ECJ in the Kofoed case has held that abuse arises when transactions are carried out 'solely for the purpose of wrongfully obtaining advantages provided for by Community law'. See ECJ: Hans Markus Kofoed v. Skatteministeriet, Case No: C-321/05, 5 July 2007, para. 38. Moreover, in the Foggia case, it was held that 'The application of EU legislation may not be extended to cover abusive practices, that is to say, transactions carried out ... but solely for the purpose of wrongfully obtaining advantages provided for by that law.' See Foggia - Sociedade Gestora de Participações Sociais SA v. Secretário de Estado dos Assuntos Fiscais, Case No: C-126/10, 10 Nov. 2011, para. 50; Justice Campbell also uses the term 'the sole purpose' to interpret the subjective (avoidance transaction) element of the Canadian GAAR. See Antle v. R. Marquis-Antle Spousal Trust v. R; Antle and another v. R, 12 ITLR 359, 18 Sept. 2009, para. 80; Also see the Opinion of Advocate General Bobek, Cussens and others, Case No: C-251/16, 7 Sept. 2017, paras 100-101; Dourado, Abuse, at 54-56. 


\subsubsection{Factual Analysis Indicates that the Transaction or Arrangement has Non-Tax and Tax Purposes}

15. If an objective analysis of all facts and circumstances surrounding the transaction/arrangement leads to the conclusion that there are several 'principal purposes', such as non-tax purposes ${ }^{57}$ and tax purposes, then the question arises as to whether the subjective element is satisfied or not? Based on a literal reading of the test, it can be argued that as long as 'one of the principal purposes' is to obtain a tax benefit, even if the transaction/arrangement has several 'principal purposes', the subjective element gets satisfied. ${ }^{58}$ Therefore, at first sight, it seems that tax authorities have tremendous discretion when applying this rule. ${ }^{59}$ This being said, in the author's opinion, if the proper factual inquiry leads to the conclusion that 'non tax purposes' outweigh 'tax purposes', then the taxpayer does not satisfy the subjective element and hence should be outside the scope of the PPT. The commentary to the PPT explicitly clarifies this position by stating that the subjective element is not applicable when a principal consideration is not to obtain a treaty benefit. It is stated, 'Where an arrangement is inextricably linked to a core commercial activity, and its form has not been driven by considerations of obtaining a benefit, it is unlikely that its principal purpose will be considered to be to obtain that benefit. ${ }^{, 60}$ This clarification has also been reflected in several examples of the PPT. For instance, refer to the fact patterns that deal with:

(1) Investments by a collective investment vehicle (CIV) and direct investment to create a plant (see section 4.3.1);

(2) investments by intermediary companies that are owned by third State residents such as entities within a multinational group like operating entities (see sections 4.3.2.1 and 4.3.2.2), entities holding share and patents (see section 4.3.2.3), service entities (see section 4.3.2.4), financing entities (see section 4.3.2.5) and intellectual property licensing entities (see section 4.3.2.6);

(3) investments by intermediary companies that are owned/set up by third States non-CIVs such as regional portfolio investment companies (see section 4.3.2.8), securitization companies (see section 4.3.2.9) or real estate companies (see section 4.3.2.10).

16. In the foregoing examples, the non-tax purposes seem to outweigh the fact that obtaining a tax benefit seemed to be one of the purpose (in some examples the tax benefit seems to be an ancillary purpose). Therefore, it is reasonable to state that when a proper factual inquiry leads to the conclusion that the transaction/arrangement is undertaken for bona fide purposes i.e. it pursues genuine commercial/ economic objectives/motives, ${ }^{61}$ then the subjective element should not be satisfied ${ }^{62}$ as 'it is unlikely that its principal purpose will be considered to be to obtain that benefit'. In other words, when non-tax purposes are primary drivers of the transaction, then it cannot be argued that 'one of the principal purposes' is to obtain a tax benefit. ${ }^{63}$ Therefore, the subjective element shall be interpreted in a 'restrictive manner' ${ }^{64}$ in the sense that if the transaction or arrangement at stake has economic or commercial justifications that outweigh the tax advantage obtained, then this element is not fulfilled.

\subsection{The Objective Element}

\subsection{Introductory Comments}

17. If the subjective element is satisfied, the taxpayer has to prove that 'granting that benefit is in accordance with the object and purpose of the relevant

\section{Notes}

57 The term non-tax purposes should be interpreted on a much more broader basis than the term 'business purposes'. See Canada Trust Co Mortgage Co v. Canada, para. 33; For an explanation on the business purpose doctrine see Chand, Thesis, s. 3.2.4.

582014 OECD, Report on Treaty Abuse, para. 17 (Commentary in para. 12); 2015 OECD, Final Report on Treaty Abuse, para. 26 (Commentary in para. 12); 2017 OECD Comm (Draft), Art. 29, para. 180.

59 KOK, PPT, at 408-409.

602015 OECD, Final Report on Treaty Abuse, para. 26 (Commentary in para. 13); 2017 OECD Comm (Draft), Art. 29, para. 181.

61 It should be noted that EU Directives, referred to previously, provide that 'arrangements' could be regarded to be genuine if they are put into place 'for valid commercial reasons which reflect economic reality'. See EU PSD, Directive 2015/121, Art. 1(3); and EU ATAD, Directive 2016/1164, Art. 6(2). Moreover, ECJ case law indicates that domestic anti-avoidance rules (such as CFC rules), which constitute a restriction to the freedoms (such as freedom of establishment), can be justified when they relate to 'wholly artificial arrangements'. In other words, if the domestic anti-avoidance rules apply to arrangements that encompass economic reality then such rules will be contrary to the freedom of establishment provisions even though the arrangement contains tax motives. See Cadbury Schweppes plc and Cadbury Schweppes Overseas Ltd v. Commissioners of Inland Revenue, Case No: C-196/04, 12 Sept. 2006, paras 68-69. Also see Chand, Thesis, s. 22.1.2.5.

62 De Broe \& Luts, BEPS, at 132; Canada Trust Co Mortgage Co v. Canada, para. 32

63 MIL (Investments) SA v. Canada, 9 ITLR 25, 18 Aug. 2006, para. 29 and para. 57; Chand, Thesis, s. 9.3.3.

64 See the Opinion of Advocate General Bobek in Cussens and others, Case No: C-251/16, 7 Sept. 2017, para. 101; De Broe, EU Law, at 211. 
provisions $^{65}$ of a tax treaty. Typically, in tax avoidance structures with tax treaties, a resident taxpayer aims to 'benefit' from (including but not limited to) (1) time limit thresholds such as the twelve month threshold provided for construction related projects; (2) ownership thresholds in the sense that substantial shareholders can benefit from the $5 \%$ dividend withholding tax rate provided in Article 10(2)(a); (3) more generally, the distributive rules contained in Article 10 - Article 13 (in treaty or rule shopping situations), often in combination with the double taxation relief provisions (Article 23) and/or with the provisions of the domestic law. ${ }^{66}$ The issue arises as to whether the taxpayer has to prove that 'granting that benefit is in accordance with' the object and purpose of the 'relevant provisions' on an isolated basis or the object and purpose of the 'relevant provisions' read in light of the overall object and purpose of the tax treaty? ${ }^{67}$

\subsubsection{Object and Purpose of the Relevant Provisions Read in Isolation}

18. At the outset, it is pertinent to note that it is difficult to understand the object and purpose of the 'relevant provisions'. 68 Tax treaties, unlike domestic legislation, are drafted in general terms without highlighting the legislature's intention to incorporate a particular rule into the tax treaty. An interpretation approach which focuses only on ordinary treaty terms will lead to the conclusion that (1) the object and purpose of a threshold provision like that of Article 5(3) is to provide a time threshold limitation; ${ }^{69}$ (2) the object and purpose of a provision like that of Article $10(2)$ is to provide for an arbitrary threshold of $25 \%$ for the purposes of determining which shareholders are entitled to the benefit of the lower rate of tax on dividends ${ }^{70}$ and (3) the general object and purpose of the relevant distributive rules (for instance, Articles 10, 11, 12 and 13) is only to allocate taxing rights and nothing more. ${ }^{71}$ In a tax avoidance scheme, a resident taxpayer always respects the formal conditions of tax treaties such as the conditions imposed by the time limit, ownership threshold or the relevant distributive rule. Therefore, the taxpayer's transaction or arrangement in every tax avoidance transaction is in accordance with the 'object and purpose of the relevant provisions'. If this approach is adopted, there is no doubt that the PPT becomes redundant, as the taxpayer will always satisfy the objective element. Such an approach, which focuses on a literal interpretation of ordinary treaty terms, should be rejected. ${ }^{72}$

\subsubsection{Object and Purpose of the Relevant Provisions to be Read in Conjunction with the Context and the Object and Purpose of the Tax Treaty}

19. Article 31(1) of the Vienna Convention on the Law of Treaties (VCLT) provides that a treaty shall be interpreted in good faith in accordance with the ordinary meaning to be given to the terms of the treaty in their context and in the light of its object and purpose'. In other words, the ordinary meaning of the terms used in tax treaties should not be interpreted literally (or in isolation) but should be interpreted in light of the tax treaties 'context' and 'object and purpose'.

20. In accordance with Article 31(2) VCLT, the 'context' of a tax treaty means the entire text of the tax treaty (including its preamble and annexes), any agreements made ancillary to the tax treaty that were mutually agreed upon by the parties to the treaty and any instruments made by one party and accepted by the other party in relation to the conclusion of a tax treaty. The documents falling into the latter two categories would typically include mutually agreed protocols, memorandums of understanding and notes

\section{Notes}

65 The EU Commission, in light of the anti-tax avoidance package, has suggested EU Member States to adopt a modified PPT. The modified PPT adds the phrase 'unless it is established that it reflects a genuine economic activity' to the objective element of the test. It is stated that the phrase has been added to adhere to the case law of the ECJ on abuse. See EU Commission, Recommendation on Treaty Abuse, at 1-4.

66 Other situations can also be envisaged (see s. 4).

67 Chand, Thesis, s. 9.3.4.

68 De Broe, EU Law, at 213.

692015 OECD, Final Report on Treaty Abuse, para. 26 (Commentary in para. 14, Example J).

70 Ibid., para. 26 (Commentary in para. 14, Example E).

71 MIL (Investments) SA v. Canada, paras 73-74; Garron and another v. R; Re Garron Family Trust; Garron v. R; St Michael Trust Corp v. R; Re Fundy Settlement; Dunin v. R; St Michael Trust Corp v. R; Re Summers by Settlement, 12 ITLR 79, 10 Sept. 2009, para. 332 \& paras 362-395; Antle v. R; Marquis-Antle Spousal Trust v. R; Antle and another v. $R$, para. 97-99; De Broe, Thesis, at 344 .

72 Chand, Thesis, s. 5.4. Another commentator highlights the issue of focussing only on the object and purpose of the relevant provisions. See Moreno, PPT, at 436-440. 
and letters exchanged during the conclusion of a tax treaty. $^{73}$ Also, in accordance with Article 31(3) VCLT, in addition to the 'context', subsequent agreements which assist in application and interpretation of a tax treaty, ${ }^{74}$ subsequent state treaty practice that establishes the agreement of the parties regarding the interpretation of the provisions of a tax treaty ${ }^{75}$ and relevant rules of international law ${ }^{76}$ should be taken into consideration in the tax treaty interpretation process. It should be noted that Article 31(2) and Article 31(3) require that all the material listed therein is in accordance with the 'common intentions' between the parties to a tax treaty. ${ }^{77}$ It follows from this that unilateral explanations issued by one party cannot be included with the ambit of Article 31 VCLT. $^{78}$

21. Furthermore, the question then arises as to what is a tax treaty's 'object and purpose'. In line with the 'textual' approach to treaty interpretation, the 'object and purpose' of a tax treaty is to be ascertained from the text of the treaty itself. Based on the text, in particular the title and preamble, the first main 'object and purpose' of a tax treaty based on the OECD Model is to avoid international double taxation (especially juridical double taxation) in order to facilitate the international exchange of goods, services, capital and persons. The objective of avoiding double taxation, in the author's opinion, is intertwined with the objective of allocating taxing rights between contracting States. This is because double taxation is eliminated as a consequence of, initially, allocating taxing rights (distributive rules contained in Articles 6-22 OECD Model) between contracting States and then applying the relief provisions (Article 23 OECD Model). ${ }^{79}$
Secondly, the author's position is that tax treaties also prevent tax evasion as more often than not the text of a treaty (preamble) sets out such an objective. ${ }^{80}$ Thirdly, the prevention of double non-taxation is not an object and purpose of a tax treaty. ${ }^{81}$ Lastly, the author takes a position that the prevention of tax avoidance is not a primary objective of a tax treaty unless and until the preamble of a treaty reflects such a conclusion (at most it is an ancillary objective). ${ }^{82}$ In this regard, it should be noted that Article 6(1) of the MLI, which represents a minimum standard, has modified the treaties preamble to read: 'Intending to eliminate double taxation with respect to the taxes covered by this agreement without creating opportunities for non-taxation or reduced taxation through tax evasion or avoidance (including through treaty-shopping arrangements aimed at obtaining reliefs provided in this agreement for the indirect benefit of residents of third jurisdictions). ${ }^{83}$ As indicated by the OECD, it is estimated that this change will be incorporated in more than 1,100 tax treaties.

22. Article 31(2) VCLT requires a treaty interpreter to refer to the preamble of the treaty. If the provision similar to Article 6(1) of the MLI is reflected in tax treaties, the author submits that the objectives of (1) allocating taxing rights and eliminating double taxation with a view to promoting cross border flows (such as investments); (2) the prevention of tax evasion; and (3) prevention of tax avoidance (in particular, treaty shopping) ${ }^{84}$ should be considered in the treaty interpretation process (while interpreting the $\mathrm{PPT}^{85}$ ) as opposed to giving preference to one of them. The addition of the tax avoidance objective will ensure that 'tax conventions apply in accordance with the purpose for which they were

\section{Notes}

73 Vogel \& Prokisch, Interpretation, at 69; Engelen, Thesis, at 429.

74 For a discussion on the legal status of mutual agreements in international law refer to Engelen, Thesis, at 431-434; Vogel \& Prokisch, Interpretation, at 70-71.

75 Engelen, Thesis, at 435

76 Ibid., at 436

77 Chand, Thesis, s. 5.4 .

78 Vogel \& Prokisch, Interpretation, at 69; Vogel, Commentary, at 38; Vogel, 2015 Commentary, at 40.

79 De Broe, Thesis, at 328; Engelen, Thesis, at 428-429; 2017 OECD Comm (Draft), Introduction, para. 15.2.

80 Van Weeghel, Thesis, at 34-35; De Broe, Thesis, at 330-331; Engelen, Thesis, at 428-429.

81 Beaulne \& Nikolakakis, Double non taxation, at 252; Lang, Double non taxation, at 86; De Broe, Thesis, at 363; De Broe \& Luts, BEPS, at 142; Chand, Thesis, s. 9.2. Also see the opinion expressed by the Canadian Tax Court in the Garron case, paras 388-390 and the Federal Court of Australia in FC of T. v. Lamesa Holdings BV, 97 ATV 4752, at 4755 .

82 Chand, Thesis, s. 5.4 .

83 See 2016 OECD, Multilateral Convention, Art. 6(1). Also see 2015 OECD, Final Report on Treaty Abuse, paras 72-74. Moreover, pursuant to Art. 6(3), an optional provision, a State 'may also choose' to include additional preamble language which would reflect that States desire to develop economic relationships and to enhance cooperation in tax matters. See 2016 OECD, Multilateral Convention, Art. 6(3)

842017 OECD Comm (Draft), Introduction, paras 16.1-16.2.

852015 OECD, Final Report on Treaty Abuse, para. 26 (Commentary in para. 5); 2017 OECD Comm (Draft), Art. 29, para. 173. 
entered into, i.e. to provide benefits in respect of bona fide exchanges of goods and services, and movements of capital and persons'. 86 Thus, the object and purpose of the 'relevant provisions' have to be read in light of the object and purpose of the entire tax treaty. Moreover, to the extent relevant, other treaty objectives such as elimination of tax discrimination as provided in Article 24 OECD Model and the establishment of a MAP as per Article 25 OECD Model should be taken into consideration. ${ }^{87}$ It is pertinent to note that the object and purpose of the relevant provisions' should be determined by reference to the treaty provisions only and not by referring to domestic (taxing) provisions in combination with treaty provisions. $^{88}$

\subsubsection{Suggested Interpretation Approach}

23. The author submits that a two-stage analysis will be required to ascertain the object and purpose of the 'relevant provisions'. Under the first stage, the taxpayer has to determine the object and purpose of the 'relevant provisions' in light of the objectives pursued by the tax treaty (legal analysis). Thereafter, under the second stage, taxpayer will have to prove that the transaction/arrangement respects the object and purpose of the 'relevant provisions' at stake (application of the legal analysis to the facts at stake). ${ }^{89}$ Consider the following positive and negative situations.

24. For instance, in Example E (positive situation) to the PPT (see margin no. 37), the facts indicate that the taxpayer satisfied the subjective element, as the sole purpose to increase his shareholding was to take benefit of the reduced rate of $5 \%$ provided under Article 10(2)(a). Under the first stage, the taxpayer will establish that (1) the object and purpose of Article 10(2)(a) is to provide for a lower withholding tax rate for substantial shareholders (2) the object and purpose of tax treaties is to (a) allocate taxing rights and eliminate double taxation with a view to promote cross border investments; (b) prevention of tax evasion and (c) prevention of tax avoidance (in particular, treaty shopping). Under the second stage, the taxpayer can establish that he has acted in accordance with (1) the object and purpose of Article 10(2)(a) in light of his compliance with the ownership requirement imposed by that provision $i$. e. owning more than $25 \%$ of the payer; and (2) the object and purpose of tax treaties as (a) he has complied with the intent of tax treaties which is to promote cross border investment; (b) the transaction does not represent a tax evasion scheme; (c) a tax avoidance motive does not exist as the transaction represents a 'genuine'/ 'bonafide' and not 'artificial' increase of shareholding. Therefore, the PPT would not apply as the taxpayer will be able to establish that the principal purpose of seeking the tax benefit was within the object, spirit and purpose of the provisions that confer the tax benefit.

25. On the other hand, in Example $\mathrm{J}$ to the PPT (see margin no. 34), the facts indicate that RCO satisfies subjective element, as one of the principal purposes (or the sole purpose) for RCO to enter into an arrangement with SUBCo is to obtain a tax benefit. Under the first stage, RCO will establish that (1) the object and purpose of Article 5(3) is to provide for a time threshold of twelve months before a taxpayer triggers a construction permanent establishment (PE) (2) the object and purpose of tax treaties is to (a) allocate taxing rights and eliminate double taxation with a view to promote cross border investments; (b) prevention of tax evasion and (c) prevention of tax avoidance. Under the second stage, RCO will be able to demonstrate that it has acted in accordance with (1) the object and purpose of Article 5(3) as it does not carry out its activities for more than twelve months; and (2) the object and purpose of tax treaties as (a) it has complied with the intent of tax treaties which is to promote cross border activities; and (b) the transaction does not represent a tax evasion scheme. With respect (c) it will be difficult for RCO to prove that its transaction represents a 'genuine'/ 'bonafide' transaction, as an objective analysis of the facts would indicate the presence of a high degree of 'artificiality'. Therefore, the PPT would apply as the taxpayer will not be able to establish that the principal purpose of seeking the tax benefit was within the object, spirit and purpose of the provisions that confer the tax benefit. This

\section{Notes}

862015 OECD, Final Report on Treaty Abuse, para. 26 (Commentary in para. 6); 2017 OECD Comm (Draft), Art. 29, para. 174.

872017 OECD Comm (Draft), Introduction, para. 15.5.

88 Antle case: para. 99.

89 See Canada Trust Co Mortgage Co v. Canada, paras 44-62; Chand, Thesis, s. 9.3.4. 
being said, the analysis would be different, at the subjective and objective level, if sufficient non-tax reasons were provided for splitting the arrangements.

\section{Application of the pPt to various FACT PATTERNS: CRITICAL COMMENTS}

\section{I Introductory Comments}

26. The commentary analyses the impact of the PPT on thirteen-fact patterns. ${ }^{90}$ It is clear that a few of these fact patterns are inspired from Court judgments. Moreover, the six additional examples, which are discussed in the context of conduit arrangements, should also be considered in light of the PPT. ${ }^{91}$ These six examples directly resemble the examples contained in the exchange of letters (EOL) between the $\mathrm{US}^{92}$ and the $\mathrm{UK}^{93}$ to interpret the anti-conduit provision contained in Article 3(1) (n) of the 2001 US-UK tax treaty, especially, with respect to the provisions dealing with dividends, ${ }^{94}$ interest $^{95}$ and royalties. ${ }^{96}$ Therefore, nineteen examples are analysed in light of the PPT. The author comments on all examples by dividing them into two groups. The first group discusses fact patterns where the application of the PPT leads to the conclusion that treaty benefits will be denied (see section 4.2). The second group discusses fact patterns where treaty benefits are to be granted (see section 4.3). Thereafter, the author concludes by discussing other fact patterns that could be subject to the PPT (see section 4.4). It should be noted that the author will not repeat the facts of each example. The reader is kindly requested to read the relevant portions of the commentary and the EOL between the US and UK on the anti-conduit provision before reading the author's comments.

\subsection{Fact Patterns Under Which the Treaty Benefit Is Denied}

\subsection{Treaty Shopping Arrangements}

27. The facts in Example $A^{97}$ are similar to the facts of the 1994 Royal Dutch Oil Company/Marketmaker judgment. ${ }^{98}$ In that case, the UK stockbroker was considered, by the Dutch Supreme Court, to be the beneficial owner of the dividends and hence was entitled to the $15 \%$ rate contained in the 1980 UK-NL tax treaty, even though the transaction was undertaken for pure tax avoidance purposes. However, in the context of Example A, the commentary states that the subject element is satisfied as 'one of the principal purposes for the arrangement under which TCO assigned the right to the payment of dividends to RCO was for RCO to obtain the benefit of the exemption from source taxation of dividends'. With respect to the objective element, the commentary provides 'it would be contrary to the object and purpose of the tax convention to grant the benefit of that exemption under this treaty-shopping arrangement'. While the author agrees with the outcome as the sole purpose of the arrangement was to avoid source taxation, a downside of this example is that it only takes into consideration the treaties overall object and purpose and does not discuss the object and purpose of the provision that is being abused i.e. Article 10.

28. Example $\mathrm{B}^{99}$ resembles the 2006 Bank of Scotland judgment. ${ }^{100}$ In that case, a US Co sold its rights to dividends on preference shares in its French subsidiary to a UK bank (the taxpayer). This was essentially done because Article 7 of the 1968 UK-French tax treaty provided that a UK resident could claim the 'avoir fiscal' from the French treasury when a dividend distribution was made to it. However, the French Supreme Court (Conseil d'Etat) denied treaty benefits to the

\section{Notes}

902015 OECD, Final Report on Treaty Abuse, para. 26 (Commentary in para. 14); 2017 OECD Comm (Draft), Art. 29, para. 182.

912015 OECD, Final Report on Treaty Abuse, para. 26 (Commentary in para. 19); 2017 OECD Comm (Draft), Art. 29, para. 187.

92 Department of the US Treasury, Exchange of Letter with the UK Inland Revenue, 19 July 2002 (Letter and Annex). In this letter, Ms Angus described six examples to explain the US approach towards the anti-conduit provision.

93 Department of the Inland Revenue, Exchange of Letter with the US Department of the US Treasury, 19 July 2002 (Letter and Annex). In this letter, Mr Makhlouf explained the UK approach towards the anti-conduit provision, in light of the six examples (facts being reversed).

94 See Art. 10(9), UK-US Tax Treaty (2001); Also see Art. 10(6), UK-Swiss Tax Treaty (1977).

95 See Art. 11(7), UK-US Tax Treaty (2001); Also see Art. 11(7), UK-Swiss Tax Treaty (1977).

96 See Art. 12(5), UK-US Tax Treaty (2001); Also see Art. 12(5), UK-Swiss Tax Treaty (1977).

972015 OECD, Final Report on Treaty Abuse, para. 26 (Commentary in para. 14, Example A); 2017 OECD Comm (Draft), Art. 29, para. 182, Example A.

98 For a detailed analysis of the judgment see De Broe, Thesis, at 694-697; Smit, Beneficial Ownership, at 61-75; See Ringler, Beneficial Ownership, at 222-223.

992015 OECD, Final Report on Treaty Abuse, para. 26 (Commentary in para. 14, Example B); 2017 OECD Comm (Draft), Art. 29, para. 182, Example B.

100 Ministre de l'Economie, des Finances et de l'Industrie v. Société Bank of Scotland, 9 ITLR 683, 29 Dec. 2006, at 683-714. 
taxpayer and ruled in favour of the tax authorities. The Court upheld the applicability of the domestic 'abuse of law' provision and provided that pursuant to this provision the arrangement was a loan from the taxpayer to the US Co which was repayable by the dividends from the French $\mathrm{Co}$ and the 'avoir fiscal' from the French treasury. In essence, the Court re-classified the transaction and upheld that the income recipient for tax purposes was the US Co. ${ }^{101}$ In the context of Example B, the commentary states that the subject element is satisfied as 'one of the principal purposes for the arrangement under which RCO acquired the usufruct of the preferred shares issued by SCO was to obtain the benefit of the 5 per cent limitation'. With respect to the objective element, the commentary provides 'it would be contrary to the object and purpose of the tax convention to grant the benefit of that limitation under this treaty-shopping arrangement'. While the author agrees with the outcome of the example as it is driven with the sole purpose to avoid source taxation, once again, the downside is that the commentary only takes into consideration the treaties overall object and purpose and does not discuss the object and purpose of the relevant provision that is being abused i.e. Article 10.

29. Example $\mathrm{A}^{102}$ to the commentary on anti-conduits directly resembles the fact pattern contained in Example 1 of the EOL with respect to the interpretation of the anti-conduit provision (Article $3(1)(\mathrm{n})$ ) in the 2001 US-UK Tax Treaty. ${ }^{103}$ In Example 1, the US considers that treaty benefits shall not be granted. However, in the reverse situation, the UK believes that although the objective test of that provision is satisfied (Article 3(1)(n)(i)), the motive test will not be met (Article 3(1)(n)(ii)). This is because UK does not impose a withholding tax on dividends and therefore there is no treaty benefit from a UK perspective. In the context of Example A, the commentary states 'This arrangement constitutes a conduit arrangement ... because one of the principal purposes for RCO participating in the transaction was to achieve a reduction of the withbolding tax for TCO'. If these facts had to be analysed under the PPT, the author's opinion is that the subjective element should be satisfied as the transaction was structured with the sole purpose to eliminate source taxation. Moreover, with respect to the objective element, if one reads Article 10 (the purpose of which is to allocate taxing rights) in light of the treaties preamble, it could be difficult for the taxpayer to establish that treaty benefits should be extended to this treaty shopping arrangement.

30. Example $\mathrm{C}^{104}$ to the commentary on anti-conduits directly resembles the fact pattern contained in Example 3 of the EOL with respect to the interpretation of the anti-conduit provision (Article 3(1)(n)) in the 2001 US-UK Tax Treaty. ${ }^{105}$ Both the US and UK consider that treaty benefits shall not be granted in that example. Moreover, the example seems to contain a mixture of facts discussed in the 1971 Aiken Industries case ${ }^{106}$ and the 1997 Northern Indiana Public Service case. ${ }^{107}$

31. In the Aiken case, a Bahamas resident corporation viz., ECL had initially given a loan to its indirect subsidiary viz., MPI, a US resident corporation. As a tax treaty did not exist between the Bahamas and the US, the interest payments made by MPI to ECL were subject to a $30 \%$ withholding tax in the US. In order to avoid this withholding tax, ECL assigned the loan to its newly incorporated indirect subsidiary viz., Industrias, a corporation resident in Honduras in exchange for several promissory notes (these notes, in principle, contained the same features of the loan that now existed between Industrias and MPL). By doing this, the taxpayer sought to take advantage of Article 9 of the 1964 USA-Honduras tax treaty, which provided that the US source interest, was exempt from the $30 \%$ withholding tax. In essence, the structure was a back-to-back loan arrangement pursuant to which the interest received by Industrias was passed on to ECL. As the structure was set up solely to avoid the US withholding tax, the US tax authorities denied the treaty benefits to

\section{Notes}

101 For a detailed analysis of the judgment see: De Broe, Thesis, at 697-702; Chand, Thesis, s. 13.4.10; Gutmann, Beneficial Ownership, at 167-182; Ringler, Beneficial Ownership, at 233-235.

1022015 OECD, Final Report on Treaty Abuse, para. 26 (Commentary in para. 19, Example A); 2017 OECD Comm (Draft), Art. 29, para. 187, Example A.

103 Exchange of Letters on the Interpretation of Art. 3(1)(n) of the US-UK Tax Treaty, Example 1.

1042015 OECD, Final Report on Treaty Abuse, para. 26 (Commentary in para. 19, Example C); 2017 OECD Comm (Draft), Art. 29, para. 187, Example C.

105 Exchange of Letters on Interpretation of Art. 3(1)(n) of the US-UK Tax Treaty, Example 3.

106 Aiken Industries, Inc vs Commissioner of Internal Revenue, 56 TC 925, 5 Aug. 1971.

107 US Court of Appeals for Seventh Circuit: Northern Indiana Public Service Company v. Commissioner, 115 F3d 506, 6 June 1997. 
Industrias. They argued that Industrias should be disregarded for tax purposes and ECL should be deemed the true owner and recipient of the interest income. The US Tax Court did agree with the tax authority's argument that the recipient of the interest income was not Industrias but ECL. The Court held that the term 'received by' as provided in Article 9 of the tax treaty was an undefined treaty term. Accordingly, pursuant to Article 2(2) of the 1964 tax treaty reference was made to the domestic tax law of the US to ascertain its meaning. Thereafter, the Court, by referring to the domestic judicial anti-avoidance doctrines, held that the interest income was 'received by' MPI as opposed to Industrias since the latter did not have any economic substance or business purpose and was set up only for tax avoidance purposes. However, the facts of the Aiken case, can be contrasted with Example $\mathrm{C}$ as in the latter case, RCO retains a spread of $1 \% .^{108}$

32. On the other hand, in the Northern Indiana Public Service (NIPS) case, the US Court of Appeals ruled in favour of the taxpayer. ${ }^{109}$ This case dealt with a structure that was set up to exploit the beneficial provisions of the 1948 USA-Netherlands tax treaty as extended to the Netherlands Antilles. A US Corporation viz., NIPSCO wished to borrow money from the Eurobond market. To achieve this NIPSCO incorporated a Netherlands Antilles corporation viz., Finance. Finance issued loan notes worth seventy million Euro on the Eurobond market at an interest rate of $17.25 \%$. Subsequently, Finance loaned the proceeds obtained from the Eurobond issue at an interest rate of $18.25 \%$ to NIPSCO. Thus, the main issue that arose in this case was whether the interest payments made by NIPSCO to Finance were eligible for treaty benefits i.e. whether the interest paid was exempt from US withholding taxes pursuant to Article 8(1) of the 1948 tax treaty? The US Court of Appeals decided the case in favour of the taxpayer by providing that:

Finance was set up to obtain capital at the lowest possible interest rates. Accessing the Eurobond market through a Netherlands Antilles subsidiary was not, at the time, an uncommon practice to accomplish this end. The record demonstrates that Finance 'was managed as a viable concern, and not as simply a lifeless facade.' ... Finance conducted recognizable business activity - concededly minimal activity, but business activity nonetheless. Significantly, Finance derived a profit. It earned income on the spread between the interest rate it charged Taxpayer on the Note (18.25 percent) and the rate it paid to the Euronote holders (17.25 percent). The foreign corporation in Aiken Industries was held to lack dominion and control because, unlike Finance, it was literally a mere conduit, earning no profit on its borrowing and lending activities ... Finance netted an annual \$700,000 from its borrowing and lending activities. That income stream had economic substance to both Taxpayer and Finance. Each time Taxpayer made an interest payment to Finance, Taxpayer's economic resources were diminished while Finance's economic position was enhanced. Finance also reinvested the annual $\$ 700,000$ interest income in order to generate additional interest income. Taxpayer had no control over Finance's reinvestments. Finally, the transactions in Aiken Industries were entirely between related parties. Finance, on the other hand, borrowed funds from unrelated third parties, the Euronote bolders.

The facts of this case, can be contrasted with Example $\mathrm{C}$ as in the latter case, the transactions are among related parties.

33. In the context of Example $\mathrm{C}$, the commentary states 'The transaction through which RCO acquired the note issued by SCO constitutes a conduit arrangement.' If these facts had to be analysed under the PPT, the author's opinion is that the subjective element should be satisfied as the transaction was structured with the sole purpose to eliminate source taxation. Moreover, with respect to the objective element, if one reads Article 11 (the purpose of the provision is to allocate taxing rights on interest related income) in light of the treaties preamble, it could be difficult for the taxpayer to establish that treaty benefits should be extended to this treaty shopping arrangement.

\subsubsection{Contract Splitting: Circumvention of the Twelve Month Threshold}

34. This fact pattern of Example $\mathrm{J}^{110}$ has been considered abusive in the OECD Commentary since 1992. ${ }^{111}$ The UN Commentary also considers

\section{Notes}

108 For a detailed analysis of the judgment see: De Broe, Thesis, at 424-426; Chand, Thesis, s. 13.4.1; Brauner, Beneficial Ownership, at 146-148; Ringler, Beneficial Ownership, at 200-202.

109 For a detailed analysis of the judgment see: De Broe, Thesis, at 426-428; Chand, Thesis, s. 13.4.4; Brauner, Beneficial Ownership, at 148-151; Ringler, Beneficial Ownership, at 206.

1102015 OECD, Final Report on Treaty Abuse, para. 26 (Commentary in para. 14, Example J); 2017 OECD Comm (Draft), Art. 29, para. 182, Example J.

1111992 OECD Comm. Art. 5, para. 18. Also see the decision of the German Federal Fiscal Court : Case No. IR 99/97, 21 Apr. 1999 as reported in the IBFD case law database. 
similar fact patterns as abusive ${ }^{112}$ in the context of construction as well as service PEs. ${ }^{113}$ In fact, Article 14 of the MLI ${ }^{114}$ (in light of BEPS Action 7) ${ }^{115}$ has recommended States to adopt a specific anti-avoidance rule (SAAR) in their tax treaties to counter contract splitting. For States that do not adopt the contract splitting provision, it becomes pertinent to check whether or not the PPT applies (whenever the PE concept in a tax treaty uses a time limit threshold). In relation to Example $J$, the author agrees that the subjective element will be satisfied, as one of the principal purposes for RCO to enter into this arrangement with SUBCo is to obtain a tax benefit (the analysis would be different if several non-tax or commercial purposes were put forward). With respect to the objective element, the commentary states 'granting the benefit of that rule in these circumstances would be contrary to the object and purpose of that paragraph as the time limitation of that paragraph would otherwise be meaningless'. In other words, the commentary seems to indicate that (1) the object and purpose of that paragraph is to provide for a time threshold of twelve months; and (2) the taxpayer can benefit from the time threshold only in genuine circumstances i.e. the transaction does not contain any abuse (tax avoidance) element such as contract splitting among related parties. Unlike the analysis in other examples, in this example the commentary discusses the object and purpose of the provision that is being abused.

\subsection{Fact Patterns Under Which Treaty Benefits are Granted}

\subsection{Direct Investment Scenarios: Two State Situations}

35. With respect to Example $\mathrm{C},{ }^{116}$ the commentary provides that the PPT rule will not apply even though the investment is made taking into consideration the benefits under the R-S treaty. This is mainly because 'the principal purpose of making the investment and building the plant' are related to RCOs expansion strategy and to benefit from low manufacturing costs ('tax purposes' seem to be ancillary). Moreover, with respect to the objective element it is stated that as 'a general objective of tax conventions is to encourage cross-border investment', obtaining the benefits is in accordance with the object and purpose of the provisions of that convention. From a tax treaty policy perspective, it is quite obvious that the PPT should not apply to these facts. However, the author wonders what tax benefits does RCO seek under the R-S tax treaty? If RCO sets up a plant in State $\mathrm{S}$, then RCO will be considered to have a PE therein under Article 5 (1) or Article 5(3). In this situation, the treaty benefit that RCO may receive is (1) an exemption or credit for the taxes paid in State $\mathrm{S}$ on the assumption that relief from double taxation is not provided in the domestic tax law of State $R$ (2) attribution of profits to the PE in accordance with the principles contained in Article 7 and not in accordance with domestic law; and (3) application of the non-discrimination provisions (Article 24(3)) to prevent State S from levying discriminatory taxation against the PE. The example needs further facts and clarifications.

36. In Example $\mathrm{D},{ }^{117} \mathrm{RCO}$ (the CIV), a tax resident of State R, invests in State S. Majority of the investors in RCO are from State $\mathrm{R}$ and a minority of investors are from other States (States that have not concluded a tax treaty with State $S$ ). At the outset, the author agrees that a tax benefit exists i.e. the withholding tax is reduced from $30 \%$ to $10 \%$. The question then arises as to whether the subject element is satisfied. The facts indicate ' $R C O$ 's investment decisions take into account the existence of tax benefits provided under State $R$ 's extensive tax convention network'. Accordingly, it could be argued that the subjective element is met. However, the facts also indicate that 'Investors' decisions to invest in $R C O$ are not driven by any particular investment made by RCO, and RCO's investment strategy is not driven by the tax position of its investors. RCO annually distributes almost all of its

\section{Notes}

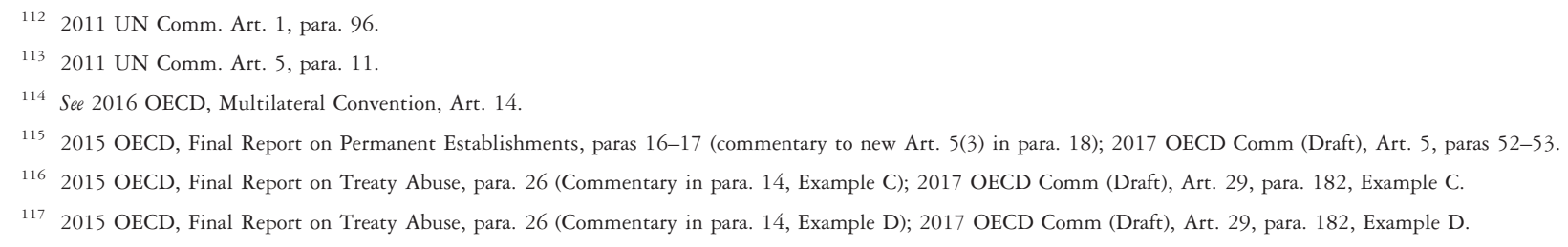


income to its investors and pays taxes in State $R$ on income not distributed during the year'. In light of these additional facts, the author's opinion is that the subjective element is not satisfied. Thus, we do not need to analyse the case under the objective element. Nonetheless, if required, with respect to the objective element, the taxpayer could argue that 'The intent of tax treaties is to provide benefits to encourage crossborder investment and, therefore, to determine whether or not paragraph 7 applies to an investment, it is necessary to consider the context in which the investment was made. In this example, the context would indicate that RCO carries out genuine investment activity in light of the funds mandate and this investment does not represent a treaty shopping arrangement wherein the income is passed on to residents of third States (rather it is passed to majority of the investors resident in State R). Arguably, based on this fact pattern, RCO may also satisfy the detailed version of the LOB clause i.e. Article $\mathrm{X}(2)(\mathrm{g}){ }^{118}$

37. The facts in example $\mathrm{E}^{119}$ indicate that RCO has held $24 \%$ of the share capital of SCO for the last five years. Following the entry into force of a tax treaty between State $\mathrm{R}$ and State $\mathrm{S}$, RCO increased its participation in SCO. This was primarily done to take benefit of the reduced rate of 5\% provided under Article 10(2)(a). The commentary provides that the PPT will not apply even though the sole principal purpose of the transaction was to obtain the treaty benefit (subjective test is satisfied). This is mainly because the taxpayer may establish that granting the benefits is in accordance with the object and purpose of Article 10(2)(a). Specifically, the taxpayer could argue that (1) Article $10(2)$ (a) uses an arbitrary threshold of $25 \%$ for the purposes of determining which shareholders are entitled to the benefit of the lower rate; and (2) the taxpayer has genuinely increased its participation in SCO i.e. its transaction does not contain any abuse (tax avoidance) element such as a quick purchase and sale. Unlike the analysis in other examples (except Example $\mathrm{J}$ on contract splitting), in this example the commentary discusses the object and purpose of the provision that the taxpayer is trying to take advantage of $i$. e. Article 10(2)(a).

\subsubsection{Investments by Intermediaries: Three (or More) State Situations}

\subsubsection{Investment by an Operating Company that Satisfies the LOB Active Conduct Test}

38. Example $\mathrm{B}^{120}$ on the commentary to anti-conduit arrangements directly resembles the fact pattern contained in Example 2 of the EOL with respect to the interpretation of the anti-conduit provision (Article 3(1)(n)) in the 2001 US-UK Tax Treaty. ${ }^{121}$ Both the US and UK consider that treaty benefits shall be granted, especially, because RCO satisfies the active conduct test of the LOB clause. ${ }^{122}$ In the context of Example B, the commentary, in line with the US and UK's position, reaches a similar conclusion. It is stated that the fact pattern refers to a:

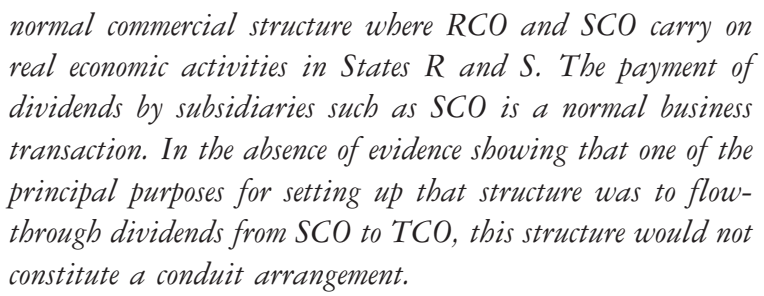

If these facts had to be analysed under the PPT, the author's opinion is that the subjective element should not be satisfied, especially, in light of several non-tax purposes. Thus, we do not need to analyse the case under the objective element. Nonetheless, if required, with respect to the objective element, if one reads Article 10 in light of the treaties preamble, the taxpayer can establish that this arrangement is not a treaty shopping arrangement whereby the income is passed on to residents of third States.

\section{Notes}

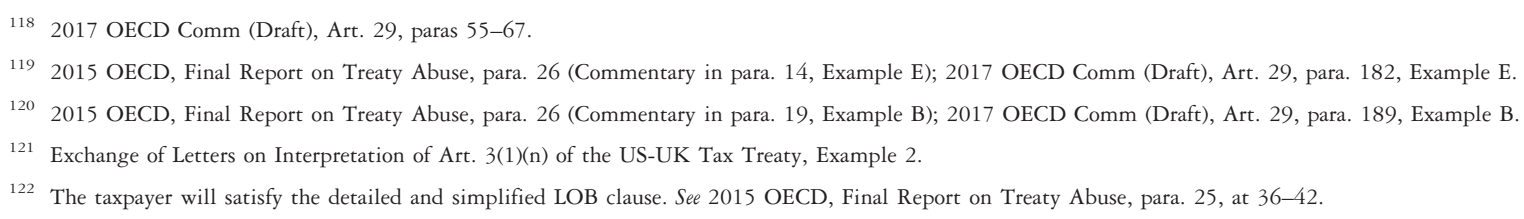




\subsubsection{Conducting International Business Through the Creation of an Operating and Holding Company}

39. In Example $\mathrm{H},{ }^{123} \mathrm{RCO}$, a tax resident of State $\mathrm{R}$, that is owned by TCO, a third State resident, invests in SCO (a tax resident of State S) through loans and equity. Although it is not clear as to what the tax treaty benefit is in this example, it is rational to assume that State $\mathrm{S}$ domestic withholding tax on interest and dividends is reduced under the R-S tax treaty.

40. The question then arises as to whether the subject element is satisfied? In this regard, several aspects need to be considered separately. The first aspect relates to establishment of RCO in State R. The facts indicate that TCO had difficulties in conducting its international business from State $T$ mainly because of issues related to transportation, time differences, limited availability of personnel fluent in foreign languages and the foreign location of business partners. Thus, in order to develop a base for its foreign business activities, TCO establishes RCO. The second aspect relates to selecting State R. It is stated that State $\mathrm{R}$ is selected because of its developed international trade and financial markets and abundance of highly qualified human resources. The third aspect relates to the activities carried out by the intermediary in State R. The facts state that RCO carries on diverse business activities such as wholesaling, retailing, manufacturing, financing and domestic and international investment. RCO's employees (personnel working in areas such as legal, finance, accounting, taxation, risk management, auditing and internal control) perform these activities. Furthermore, RCO possesses the necessary financial resources to conduct its activities. Consequently, in light of the three aspects, it is clear that RCO carries out genuine economic activities that may constitute an active conduct of business. The fourth aspect relates to RCOs investment in SCO. The facts indicate that RCO, as part of its business activities, also invests in SCO through loans and equity.

41. Given these facts, it is clear that RCOs creation in State R and its investment in SCO are not driven with the purposes of avoiding taxes in State S. Therefore, the subjective element should not be satisfied. The commentary correctly reaches this conclusion and states ' $R C O$ has been established for business efficiency reasons and its financing of SCO through equity and loans is part of RCO's active conduct of a business in State R'.

\subsubsection{Acquisition of a Holding Company that Owns Shares and Patents}

42. In Example F, ${ }^{124} \mathrm{RCO}$, a tax resident of State $\mathrm{R}$ that is owned by private residents of the same State, is the family owned holding company of a group that is active in the information technology (IT) sector. RCOs key assets consist of shares in several neighbouring subsidiaries, including a subsidiary in State $\mathrm{S}(\mathrm{SCO})$, and patents that are licensed to the subsidiaries, including to SCO. Dividends and royalties stemming from these shares and patents are subject to low/nil taxes in the State of source (including State S) due to favourable tax treaties. TCO (listed company), a resident of State T, which operates in the IT business, acquires the shares of RCO in order to expand its business. State $\mathrm{T}$ does not have a tax treaty with State S. Based on this fact pattern; can the PPT be applied to RCO to deny treaty benefits with respect to the dividend and royalty income? In the author's opinion, this should not be the case. With respect to the subjective element the commentary correctly states 'it would be reasonable to conclude that the principal purposes for the acquisition of $R C O$ are related to the expansion of the business of the TCO group and do not include the obtaining of benefits under the treaty between States $R$ and $S$. The fact that $R C O$ acts primarily as a bolding company does not change that result'. This being said, the example does not provide detailed facts with respect to post acquisition scenarios. The commentary states:

It might well be that, after the acquisition of the shares of RCO, TCO's management will consider the benefits of the tax treaty concluded between State $R$ and State $S$ before deciding to keep in RCO the shares of SCO and the patents licensed to SCO. This, however, would not be a purpose related to the relevant transaction, which is the acquisition of the shares of $R C O .{ }^{125}$

\section{Notes}

1232015 OECD, Final Report on Treaty Abuse, para. 26 (Commentary in para. 14, Example H); 2017 OECD Comm (Draft), Art. 29, para. 182, Example H.

1242015 OECD, Final Report on Treaty Abuse, para. 26 (Commentary in para. 14, Example F); 2017 OECD Comm (Draft), Art. 29, para. 182, Example F.

125 It should be noted that Danish Courts have ruled on whether or not acquisition vehicles can be considered to be 'beneficial owners' for the purposes of the articles that deal with dividend and interest in Danish tax treaties. See Bundgaard, Beneficial Ownership, at 94-108; Ringler, Beneficial Ownership, at 251-260. 


\subsubsection{Intra Group Services Company}

43. In Example G, ${ }^{126}$ RCO, a tax resident of State $\mathrm{R}$, that is owned by TCO, a third State resident, provides intra group services to five associated enterprises. Although it is not clear as to what the tax treaty benefit is in this example, it is rational to assume that the tax treaties between State $\mathrm{R}$ and the States of the associated enterprises, restrict the latter States from imposing their domestic withholding taxes on service related income. For example, let's assume that the domestic law of the source State imposes a high withholding tax on services income $(20 \%)$. The taxpayer could then contend that Article 7 restricts the State of source from taxing that services income unless and until a PE exists therein. Alternatively, if the treaty contains a fee for technical services provision, which provides for a lower rate $(10 \%)$, it could be contended that the lower rate should be applied.

44. The question then arises as to whether the subject element is satisfied? The first aspect relates to establishment of RCO in State R. The facts indicate that TCO establishes RCO, a regional company, for the purpose of providing intra group services to its associated enterprises. Such services include management related services (such as accounting, legal advice and human resources), ${ }^{127}$ financing and treasury services (such as managing currency risks and arranging hedging transactions) ${ }^{128}$ and other nonfinancing related services. The second aspect relates to selecting State R. After considering different locations, TCO chooses State R because of the availability of skilled work force, dependable legal system, business friendly setting, political stability, membership of a regional block, sophisticated banking industry and the comprehensive double taxation treaty network of State R, including its tax treaties with the five States in which TCO owns subsidiaries. The third aspect relates to the activities carried out by the intermediary in State R.
45. If an accurate delineation of the transaction ${ }^{129}$ through a proper functional analysis ${ }^{130}$ indicates that RCO (1) through its personnel renders the services to the associated enterprises (2) RCO employs tangible assets in providing its services and (3) RCO, through its personnel, controls and has the financial capacity to assume the risks associated with the services, ${ }^{131}$ then it is clear that RCO carries out genuine economic activity for which it should be entitled to service related fees from its associated enterprises. Therefore, the subjective element should not be satisfied. The commentary correctly reaches this conclusion and states 'it would not be reasonable to deny the benefits of the treaties concluded between State $R$ and the five States where the subsidiaries operate'.

\subsubsection{Intra Group Financing Company}

46. Example $\mathrm{F}^{132}$ to the commentary on anti-conduits directly resembles the fact pattern contained in Example 6 of the EOL with respect to the interpretation of the anti-conduit provision (Article 3(1)(n)) in the 2001 US-UK Tax Treaty. ${ }^{133}$ The US, being the source State, considers that treaty benefits shall be granted as the UKCo performs significant activities and the main purposes of entering into the arrangement is not for avoiding US withholding tax. Likewise in the reverse situation, the UK, being the source State, considers that treaty benefits shall also be granted, as the USCO appears to be a real business performing substantive economic functions, using real assets and assuming real risks. Further, the USCO appears to be bearing the interest rate and currency risk and thus carries out its business in a commercial manner. In the context of Example F, the commentary, in line with the US and UK's position, states in the absence of facts which would indicate that 'one of the principal purposes for these loans was the avoidance of withbolding tax in State $S$, the loan from TCO to RCO and the loan from RCO to SCO do not constitute a conduit arrangement'.

\section{Notes}

1262015 OECD, Final Report on Treaty Abuse, para. 26 (Commentary in para. 14, Example G); 2017 OECD Comm (Draft), Art. 29, para. 182, Example G.

127 These services seem to be low value added services. See OECD, Transfer Pricing Guidelines, para. 7.49.

128 These services cannot be considered to be low value added services. See OECD, Transfer Pricing Guidelines, para. 7.47.

129 See OECD, Transfer Pricing Guidelines, paras 1.35-1.36.

130 Ibid., paras $1.51-1.55$.

131 Ibid., paras $1.56-1.106$.

1322015 OECD, Final Report on Treaty Abuse, para. 26 (Commentary in para. 19, Example F); 2017 OECD Comm (Draft), Art. 29, para. 187, Example F.

133 Exchange of Letters on Interpretation of Art. 3(1)(n) of the US-UK Tax Treaty, Example 6. 
47. If these facts had to be analysed under the PPT, the author's opinion is that the subjective element should not be satisfied. This is because (1) RCO is established with the purpose of carrying out financing activities and (2) RCO carries out these activities through fifty employees (3) RCO employs the relevant assets; and (4) RCO, through its personnel, controls and has the financial capacity to assume the risks (financial risks) ${ }^{134}$ associated with those activities. ${ }^{135}$ In other words, RCO carries out genuine economic activity and its investment in SCO is made in light of its core treasury business.

\subsubsection{Intra Group Intellectual Property Licensing}

48. Example $\mathrm{E}^{136}$ on the commentary on anti-conduit arrangements directly resembles the fact pattern contained in Example 5 of the EOL with respect to the interpretation of the anti-conduit provision (Article 3(1)(n)) in the 2001 US-UK Tax Treaty. ${ }^{137}$ The US, being the source State, considers that treaty benefits shall be granted and the transaction shall not be considered as a conduit arrangement. The UK in the reverse situation, on the other hand, believes that although the objective test of that provision is satisfied (income is being forwarded), the motive test will not be met. It is stated that as:

$X C_{0}$ is conforming to the standard commercial organisation and behaviour of the group in the way that it structures its licensing and sub-licensing activities and assuming the same structure is employed with respect to other subsidiaries carrying out similar activities in countries which have treaties which offer similar or more favourable benefits, the inference would be that the absence of a treaty between country $X$ and the $U K$ is not influencing the motive for the transactions described. Therefore even though the specific fact pattern, as presented, meets the first part of the definition of a 'conduit arrangement' at Article $3(l)(n)(i)$, on balance the conclusion would be that the main purpose or one of the main purposes' of the transactions was not the obtaining of UK/US treaty benefits. So the structure would not constitute a conduit arrangement.

In the context of Example E, the commentary, in line with the UK's position, reaches a similar conclusion. If these facts had to be analysed under the PPT, the author's opinion is that the subjective element should not be satisfied. This is because the licensing transactions are driven primarily by nontax purposes (commercial reasons) and are not structured with the sole intention to eliminate source taxation. Thus, we do not need to analyse the case under the objective element. ${ }^{138}$

\subsubsection{Funding by a Unrelated Bank in Light of a Bank Deposit}

49. Example $\mathrm{D}^{139}$ on anti-conduit arrangements, directly resembles the fact pattern contained in Example 4 of the EOL with respect to the interpretation of the anti-conduit provision (Article 3 (1)(n)) in the 2001 US-UK Tax Treaty. ${ }^{140}$ The US, being the source State, considers that treaty benefits shall be granted and the transaction shall not be considered as a conduit arrangement. This is because the "UKCo is unrelated to USCO and XCo in determining whether there is a conduit arrangement. Accordingly, this will be treated as a conduit arrangement only if UKCo would not have entered into the transaction on substantially the same terms in the absence of the XCo deposit. Under these facts, there is no conduit arrangement'. ${ }^{141}$ On the other hand, the UK, being the source State, differentiates between two situations. The first scenario provides that the USCO lends to the UKCo without a matching collateral deposit from XCo (and in light of other reasons) and the second scenario provides that the USCO lends to the UKCo only in light of a matching collateral deposit from XCo.

\section{Notes}

134 See OECD, Transfer Pricing Guidelines, paras 1.56-1.106.

135 Chand, Loans, at 896-898; Chand, Cash Pooling, at 40-42.

1362015 OECD, Final Report on Treaty Abuse, para. 26 (Commentary in para. 19, Example E); 2017 OECD Comm (Draft), Art. 29, para. 187, Example E; Also see the discussion on the US SDI Netherlands (1996) case in Brauner, Beneficial Ownership, at 149-154; Ringler, Beneficial Ownership, at 207-208. Also see the Velcro Canada Case (2012) in Arnold, Beneficial Ownership, at 44-48; Ringler, Beneficial Ownership, at 229-230.

137 Exchange of Letters on Interpretation of Art. 3(1)(n) of the US-UK Tax Treaty, Example 5.

138 This being said, one may question whether the intermediary should be entitled to the returns from a transfer pricing perspective. See OECD, Transfer Pricing Guidelines, paras 6.47-6.72.

1392015 OECD, Final Report on Treaty Abuse, para. 26 (Commentary in para. 19, Example D); 2017 OECD Comm (Draft), Art. 29, para. 187, Example D.

140 Exchange of Letters on Interpretation of Art. 3(1)(n) of the US-UK Tax Treaty, Example 4.

141 Also see Rev. Rul. 87-89, 1987-2, C.B. 195; Ringler, Beneficial Ownership, at 205-206. 
50. With respect to the second situation, the UKs position is that:

if USCO's decision to lend to UKCo was dependent on XCo providing a matching collateral deposit to secure the loan, the indication would be that XCo was in substance lending to $U K C o$ direct but in form routing the loan through a bank with whom it has a close relationship in order to obtain the benefit of the treaty. In such circumstances the transactions would constitute a conduit arrangement as defined by the treaty.

In the context of Example D, the commentary, in line with the UK's position, reaches a similar conclusion. If these facts had to be analysed under the PPT, the author's opinion is that the subjective element should be satisfied as the transaction was structured with the sole purpose to eliminate source taxation. Moreover, with respect to the objective element, if one reads Article 11 in light of the treaties preamble, it could be concluded 'it would be contrary to the object and purpose of the tax convention to grant the benefit of that exemption under this treaty-shopping arrangement'.

51. On the other hand, with respect to the first situation, the UKs position is that:

The fact that UK/US treaty benefits are available if UKCo borrows from USCO, and that similar benefits might not be available if it borrowed elsewhere, is clearly a factor in UKCo's decision (which may be influenced by advice given to it by its $100 \%$ sharebolder). It may even be a decisive factor, in the sense that, all else being equal, the availability of treaty benefits may swing the balance in favour of borrowing from USCO rather than from another lender. However, whether the obtaining of treaty benefits was 'the main purpose or one of the main purposes' of the transaction would have to be determined by reference to the particular facts and circumstances. Similarly, for the anti-conduit provision to apply it would have to be established that the interest paid by UKCo was 'flowing through' USCO to XCo.... On the specific facts as presented, the transactions would not constitute a conduit arrangement as defined by the treaty.

In the context of Example D, the commentary, in line with the UK's position, reaches a similar conclusion. The author agrees with this outcome.

\subsubsection{Investment by a Regional Portfolio Investment Company}

52. In Example $\mathrm{K},{ }^{142}$ an institutional investor, a State $\mathrm{T}$ resident, wholly owns RCO, a tax resident of
State R. RCO acts as a regional investment platform that acquires and manages a diversified portfolio of private market investments in several States (including State R). RCO invests in SCO, a resident of State $\mathrm{S}$. The treaty benefit that RCO derives is that the State $\mathrm{S}$ domestic withholding tax on dividends is reduced from $30 \%$ to $5 \%$ under the R-S tax treaty.

53. The question then arises as to whether the subject element is satisfied? In this regard, several aspects need to be considered separately. The first aspect relates to establishment of RCO in State R. It is clear that the fund establishes RCO to generate investment related returns through the acquisition and management of a diversified portfolio of private market investments. The second aspect relates to selecting Sate $\mathrm{R}$. The facts indicate that State $\mathrm{R}$ was selected because of (1) the availability of knowledgeable directors with knowledge of regional business practices and regulations (2) the existence of a skilled multilingual workforce (3) State R's membership of a regional grouping and (4) the extensive tax convention network of State $\mathrm{R}$, including its tax convention with State S, which provides for low withholding tax rates. The third aspect relates to the activities carried out by the intermediary in State $\mathrm{R}$. The facts state that RCOs activities are carried out by (1) a board of directors that are comprised of a majority of State $\mathrm{R}$ residents (with expertise in investment management) and the members of Fund's global management team; and (2) an experienced local management team that reviews investment recommendations from the Fund and performs various other functions such as approving and monitoring investments, carrying on treasury functions, maintaining RCO's books and records, and ensuring compliance with regulatory requirements in States where it invests. In light of these three aspects, it is clear that RCO's carries out genuine economic activities in State R. The fourth aspect relates to RCOs investment in SCO. The facts indicate that $\mathrm{RCO}$, in addition to other investments in the region, also invests in SCO.

54. Given these facts, it is clear that RCOs creation in State $\mathrm{R}$ and its investment in SCO are not driven with the principal purpose of avoiding taxes in State $\mathrm{S}$ even though ' $R C O$ considers the existence of a benefit under the State $R$-State $S$ tax convention with

\section{Notes}

1422017 OECD, Discussion Draft on Non-CIV Examples, para. 9 (Example 1); 2017 OECD Comm (Draft), Art. 29, para. 182, Example K. 
respect to dividends'. Therefore, the subjective element should not be satisfied. The commentary correctly reaches this conclusion and states that as "the intent of tax treaties is to provide benefits to encourage cross-border investment it is not reasonable (for the tax authorities) 'to deny the benefit of the State R-State $S$ tax convention to $R C O$ '.

\subsubsection{Investment by a Securitization Company}

55. In Example $\mathrm{L},{ }^{143}$ a bank, a State $\mathrm{T}$ resident, establishes RCO, a tax resident of State R. RCO acts as a securitization company. The bank sells its portfolio of loans and other receivables owed by debtors located in several jurisdictions to RCO. A majority of RCOs portfolio $(60 \%)$ consists of receivables from State $\mathrm{S}$. RCO receives interest income regularly from its State $\mathrm{S}$ receivables. The treaty benefit that RCO derives is that the State $\mathrm{S}$ domestic withholding tax on interest is reduced from $30 \%$ to $10 \%$ under the R-S tax treaty (the T-S treaty also provides for a similar rate).

56. The question then arises as to whether the subject element is satisfied? In this regard, several aspects need to be considered separately. The first aspect relates to establishment of RCO in State R. It is clear that the bank establishes RCO to carry out a securitization related activity. In this regard, it is stated that (1) RCO is debt funded (2) RCO's debt finance was raised through the issuance of notes that are widely held by third-party investors (3) the notes are listed on a recognized stock exchange (4) to comply with regulatory requirements, the bank has also retained a small percentage of the listed, widely held debt securities issued by RCO. The second aspect relates to the reasons for selecting State R. The facts indicate that State $\mathrm{R}$ was selected because of several reasons such as (1) State R's robust securitization framework (2) its securitization and other relevant legislation (3) the availability of skilled and experienced personnel and support services in State $\mathrm{R}$ and (4) the existence of tax benefits provided under State R's extensive tax convention network. Furthermore, the facts indicate that investors' decisions to invest in RCO are not driven by any particular investment made by RCO and RCO's investment strategy is not driven by the tax position of the investors. RCO is also taxed in State R on income earned and is entitled to a full deduction for interest payments made to investors. The third aspect relates to the activities carried out by the intermediary in State R. Let's assume that RCOs activities are overseen by a competent board of directors that are comprised of a majority of State $\mathrm{R}$ residents and an experienced local management team performs the day to day activities (the days to day activities could also be outsourced but would continue to be controlled by the directors). In light of the three aspects it is reasonable to determine that RCO carries out genuine economic activities that constitute an active conduct of a business in State $\mathrm{R}$. The fourth aspect relates to the sale of receivables. Let's assume that the sale takes place on an arm's length basis.

57. In this situation, it is obvious that RCOs creation in State $\mathrm{R}$ and its purchase of receivables are not driven with the purposes of avoiding taxes in State $\mathrm{S}$ even though the "bank and RCO considered the existence of a benefit under the State R-State $S$ tax convention with respect to interest'. Therefore, the subjective element should not be satisfied. The commentary correctly reaches this conclusion and states that as 'the intent of tax treaties is to provide benefits to encourage cross-border investment' it is not reasonable (for the tax authorities) 'to deny the benefit of the State R-State S tax convention to $R C O$ '. As the subjective element is not satisfied, the objective element need not be analysed. In the opinion of the author, the outcome should be similar even if the T-S treaty provides for a higher rate as compared to the R-S treaty. ${ }^{144}$

\subsubsection{Investment by a Real Estate Investment Company}

58. In Example $\mathrm{M}^{145}$ a real estate fund, a State $\mathrm{C}$ transparent partnership is established to invest in real estate across a particular region. A regulated fund manager manages the fund. The investors in the fund comprise of institutional investors such as pension funds, sovereign wealth funds and a range of other investors. The investment strategy of the fund is based on investing in real estate assets,

\section{Notes}

1432017 OECD, Discussion Draft on Non-CIV Examples, para. 9 (Example 2); 2017 OECD Comm (Draft), Art. 29, para. 182, Example L.

144 However, the HMRC would not agree with this outcome and challenge the structure by contending that that the securitization vehicle in not the 'beneficial owner' of the interest income. See Examples 1, 2 and 3 discussed in HMRC, Double taxation claims and applications - Beneficial ownership, INTM 332080.

1452017 OECD, Discussion Draft on Non-CIV Examples, para. 9 (Example 3); 2017 OECD Comm (Draft), Art. 29, para. 182, Example M. 
maximizing their value and realizing appreciation through the disposal of the investments. The strategy is not driven by tax considerations. The real estate fund establishes and invests in RCO, a tax resident of State R. RCO acts as a holding company. RCO establishes several wholly owned subsidiaries in different source States. These subsidiaries purchase and own the real estate. RCO invests in these subsidiaries through debt and equity. Although it is not clear as to what the tax treaty benefit is in this example, it is rational to assume that the tax treaties between State $\mathrm{R}$ and the States of the local subsidiary companies, restrict the latter States from imposing their domestic withholding taxes on investment related income such as dividends, interest and capital gains.

59. The question then arises as to whether the subject element is satisfied with respect to the PPT in the tax treaty between State $\mathrm{R}$ and the other States in which the investment is made? In this regard, several aspects need to be considered separately. The first aspect relates to establishment of RCO in State R. The facts indicate that RCO was established for several commercial and legal reasons such as (1) to protect the real estate fund from the liabilities of and potential claims against the fund's immovable property assets (2) to facilitate debt financing (including from third-party lenders) and the making, management and disposal of investments (3) for administering the claims for relief of withholding tax under any applicable tax treaty. It is indicated that this is an important function as it is administratively simpler for one company to get treaty relief rather than have each institutional investor process its own claim for relief, especially if the treaty relief to which each investor would be entitled as regards a specific item of income is a small amount. The second aspect relates to the reasons for selecting State $R$. The facts indicate that State $\mathrm{R}$ was selected due to its (1) politically stable environment (2) its regulatory and legal system (3) lender and investor familiarity (4) access to appropriately qualified personnel and (5) the extensive tax convention network of State $\mathrm{R}$, including its treaties with other States within the specific geographic area targeted for investment. It is also stated that RCO does not obtain treaty benefits that are better than the benefits the investors in the fund would have received if they had made the same investments directly in these States. The third aspect relates to the activities carried out by the intermediary in State R. Let's assume that RCOs activities are 1 ) overseen by a competent board of directors that are comprised of a majority of State $\mathrm{R}$ residents; and 2) an experienced local management team performs the day to day activities (the days to day activities could also be outsourced but would continue to be controlled by the directors). The fourth aspect relates to the investment by RCO in various States. The facts indicate that RCO makes several investments in the region in light of the funds strategy.

60. Given these facts, RCOs creation in State R and its investment in several source States are 'made for commercial purposes consistent with the investment mandate of the fund'. Moreover, RCO does not derive any treaty benefits that are better than those to which its investors would be entitled if they received the income derived directly from such investments. Therefore, even though 'the decision to locate RCO in State $R$ is taken in light of the existence of benefits under the tax conventions between State $R$ and the States within the specific geographic area targeted for investment', it is not reasonable (for the tax authorities) to 'deny the benefit of the tax treaties between RCO and the States in which RCO's immovable property investments are located'. As the subjective element is not satisfied, the objective element need not be analysed.

\subsubsection{Collection of Royalties by a Collective Management Association}

61. Example $\mathrm{I}^{146}$ is indeed a strange example. It seems to be inspired from a Spanish case that dealt with royalties received by societies on management of author's rights ${ }^{147}$ or the practise adopted by the UK tax authorities ${ }^{148}$ to administer claims made by overseas collecting societies. The example will be discussed only from a State $\mathrm{R}$ perspective, as the outcome is similar in the reverse situation. In this example, several performers and copyright holders

\section{Notes}

1462015 OECD, Final Report on Treaty Abuse, para. 26 (Commentary in para. 14, Example I); 2017 OECD Comm (Draft), Art. 29, para. 182, Example I.

147 For a detailed analysis of the judgment see: Jimenez, Beneficial Ownership, at 191-201.

148 See HMRC, Double Taxation applications and claims: Applicants/claimants, INTM 338000. 
from various countries appoint $\mathrm{RCO}$, a tax resident of State R, as an agent to manage their rights. RCO has an agreement with SCO, a State $\mathrm{S}$ tax resident, pursuant to which SCO assists RCO to license the rights to independent users in State S. SCO receives the royalties and passes them to RCO and then $\mathrm{RCO}$, net of an agency commission, passes the royalty income to the right holders. SCO has agreed with the State $S$ tax administration that it will apply the tax treaty between the State of residence of the right holder (the beneficial owner) and State $S$ to determine the withholding tax on royalty payments that has to be paid to State S. Can the PPT be applied to this arrangement?

62. In the opinion of the author, this fact pattern should not be analysed under the PPT rule. The facts indicate that the relevant treaty that applies is the treaty between the State of residence of the right holder and State S. If the treaty is applied in an accurate manner then logically the PPT should not be applied. Moreover, this fact pattern does not contain any element that indicates that a principal purpose of the arrangement is to obtain a treaty benefit. This example should, thus, be deleted as it only demonstrates the correct and efficient application of tax treaties.

\subsection{Other Fact Patterns that Could Be Subject to the PPT}

63. Several other fact patterns discussed in the commentary, in addition to the nineteen fact patterns discussed in this contribution, could be analysed with respect to the PPT. For instance, fact patterns dealing with structures that take advantage of lower rates for dividends, ${ }^{149}$ structures that avoid source taxation on capital gains from sale of shares of real estate companies ${ }^{150}$ and structures that avoid source taxation in triangular cases with $\mathrm{PEs}^{151}$ could be analysed under the PPT. Nevertheless, the OECD has given States the option to counter abuse arising from such fact patterns through the adoption of treaty SAARs that are reflected in Article $8,{ }^{152}$ Article $9^{153}$ and Article 10 of the MLI ${ }^{154}$. Moreover, other fact patterns that deal with transfer of residence prior to alienation of assets, ${ }^{155}$ income recharacterizations, ${ }^{156}$ international hiring out of labour structures, ${ }^{157}$ rent a star structures ${ }^{158}$ and salary splits for director fee remuneration ${ }^{159}$ could be analysed under the PPT.

\section{The consequence of DeNYING tReATY BENEFITS}

\section{I The Discretionary Relief Clause and the Issues Surrounding that Provision}

64. Consider the following rule-shopping scheme. $\mathrm{Mr} \mathrm{X}$, a resident of State $\mathrm{R}$, owns a subsidiary viz., Corp $\mathrm{S}$ (with significant reserves), a resident of State $\mathrm{S}$. In term of taxes, State $\mathrm{S}$ levies a domestic withholding tax of $35 \%$ on dividends paid by its resident corporations to non-residents and State $\mathrm{R}$ does not tax capital gains. Further, States $\mathrm{R}$ and $\mathrm{S}$ have concluded a tax treaty based on the OECD Model. If Corp $\mathrm{S}$ distributes a dividend then State $\mathrm{S}$ will apply its domestic withholding tax, which can ultimately be reduced under the R-S tax treaty in accordance with Article 10(2) (15\% as it is an individual taxpayer). To avoid the State $\mathrm{S}$ withholding tax on dividends, $\mathrm{Mr} \mathrm{X}$ sells the shares of Corp $\mathrm{S}$ to a related corporation $\mathrm{ABC}$, which is also a resident of State $S$, in exchange for a promissory/ loan note. This sale is taxable only in State $R$ pursuant to Article 13(5) of the R-S tax treaty - even if State $\mathrm{S}$ taxes capital gains derived by non-residents pursuant to its domestic law. Thereafter, $\mathrm{ABC}$ instructs Corp $\mathrm{S}$ to distribute a dividend.

\section{Notes}

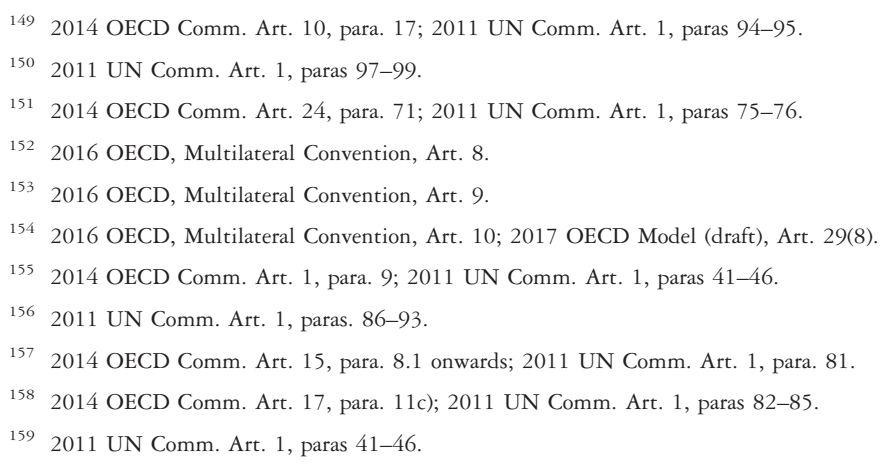


The receipt of dividend by $\mathrm{ABC}$ is mostly tax exempt (pursuant to a domestic dividend exclusion system for inter-corporate dividends or a domestic participation exemption regime). Soon afterwards, $\mathrm{ABC}$ uses those proceeds to pay off the promissory/ loan note due to $\mathrm{Mr} \mathrm{X}$. Thus, by engaging is such a transaction, $\mathrm{Mr} \mathrm{X}$ converts dividend income falling under Article 10(2)(b) of the R-S tax treaty into a capital gain falling under Article 13(5). Assume the PPT applies to this transaction and treaty benefits (the benefit of exempting capital gains from source taxation) are not granted. Does this mean that the item of income will be taxable as per the domestic law of the source State $(35 \%)$ or can the taxpayer still invoke the provisions of Article 10(2) (15\%) and request for treaty relief?

65. If treaty benefits are denied pursuant to the guiding principle then the author's view is that the lower rate of $15 \%$ should apply automatically. However, the OECD's initial view, in the context of the PPT, was that the item of income should then be taxed as per the domestic law of the source State. ${ }^{160}$ Nevertheless, in light of the public comments it received pursuant to its follow up work in November 2014, the final report on Action 6 suggested States to incorporate an alternate treaty provision which would enable the competent authorities (tax authorities) to provide discretionary relief. ${ }^{161}$ The provision, which does not represent a minimum standard, is also reflected in the MLI. It states that pursuant to Article 7(3), ${ }^{162}$ the Party that chooses to apply the PPT 'may also choose' to apply the discretionary relief rule contained in Article 7(4). ${ }^{163}$

66. The provision provides that:

Where a benefit under a Covered Tax Agreement is denied to a person ... the competent authority ... shall nevertheless treat that person as being entitled to this benefit, or to different benefits with respect to a specific item of income or capital, if such competent authority, upon request from that person and after consideration of the relevant facts and circumstances, determines that such benefits would have been granted to that person in the absence of the transaction or arrangement.
In the absence of the 'transaction or arrangement' i.e. the rule-shopping scheme, $\mathrm{Mr} \mathrm{X}$ would have been entitled to a lower rate of $15 \%$. Therefore, if the provision is incorporated in the R-S tax treaty, the competent authorities, after a review of the facts and circumstances, may provide discretionary relief to $\mathrm{Mr} \mathrm{X}$.

67. Interesting issues arise with respect to the scope of the provision in another rule shopping situation. Assume that an individual taxpayer, $\mathrm{Mr}$ $\mathrm{X}$ (that is entitled to a $15 \%$ rate under Article 10 (2)(b)) sells its shares to a related company viz., Co $\mathrm{X}$ (that is entitled to a $5 \%$ rate under Article 10 (2)(a)), both residents of State R, prior to a dividend distribution by a company resident in State $\mathrm{S}$. Assume the PPT applies and the $5 \%$ benefit is denied to Co X. In this situation, can Co X (the taxpayer who was denied the benefit) invoke the discretionary relief clause and claim for the application of a $15 \%$ rate? In the absence of the 'transaction or arrangement' i.e. the rule-shopping scheme, Co X would still be entitled to the $5 \%$ rate (if it satisfies the ownership threshold). Therefore, it does not make sense for Co $\mathrm{X}$ to make the claim. In this circumstance, it is more appropriate for $\mathrm{Mr} \mathrm{X}$ to claim for discretionary benefits before the competent authorities. However, the competent authorities could deny the application of this clause to $\mathrm{Mr} \mathrm{X}$ by arguing that the benefit under the R-S tax treaty was denied to $\mathrm{Co} \mathrm{X}$ and not $\mathrm{Mr}$ $\mathrm{X}$. Nevertheless, the commentary answers the question in the affirmative and states that the discretionary relief "provision would allow the competent authority of State $S$ to grant the benefit of the reduced rate provided for in subparagraph b) of paragraph 2 of Article 10 if that competent authority determined that such benefit would have been granted in the absence of the assignment to another company of the right to receive dividends'. ${ }^{164}$ Thus, a mismatch exists between the text and the commentary to the text.

68. Furthermore, consider the treaty shopping case discussed in Example $\mathrm{C}^{165}$ to the commentary on

\section{Notes}

1602014 OECD, Follow up work on BEPS Action 6: Preventing Treaty Abuse, at 10-11.

1612015 OECD, Final Report on Treaty Abuse, para. 26 (Commentary in para. 16); 2017 OECD Comm (Draft), Art. 29, para. 184.

1622016 OECD, Multilateral Convention, Art. 7(3).

1632016 OECD, Multilateral Convention, Art. 7(4).

1642015 OECD, Final Report on Treaty Abuse, para. 26 (Commentary in para. 18); 2017 OECD Comm (Draft), Art. 29, para. 186.

1652015 OECD, Final Report on Treaty Abuse, para. 26 (Commentary in para. 19, Example C); 2017 OECD Comm (Draft), Art. 29, para. 187, Example C. 
anti-conduits (see section 4.2.1). In that example, RCO is denied the zero rate withholding tax under the R-S tax treaty. Assume that a tax treaty exists between State $\mathrm{T}$ and State $\mathrm{S}$ and that treaty provides for a $10 \%$ withholding tax on interest. Can RCO (the taxpayer who was denied the benefit) invoke the discretionary relief clause (in the R-S tax treaty) and claim for the application of a $10 \%$ rate (in the T-S tax treaty)? In the absence of the 'transaction or arrangement' i.e. the treaty-shopping scheme, RCO would still be entitled to the zero rate (if its investment represents a genuine investment). Therefore, it does not make sense for RCO to make the claim. In this circumstance, it is more appropriate for TCO to claim for discretionary benefits before the competent authorities. However, the competent authorities could deny the application of this clause to TCO by arguing that the benefit under the R-S tax treaty was denied to RCO and not TCO. A drafting flaw emerges in the text of the provision, as the 'person' who is denied the treaty benefit under the PPT should be the same 'person' to whom discretionary relief can be provided.

69. Based on the foregoing discussion, the author makes two submissions. Firstly, the references to the term 'person' in Article 7(4) should be deleted as that reference narrows the scope of applying the clause. ${ }^{166}$ Secondly, treaty benefits should be granted to the taxpayer automatically rather than subjecting the taxpayer to seek relief under an administrative mechanism, which could end up being burdensome. ${ }^{167}$ Thus, the clause should be redrafted. ${ }^{168}$

\subsection{Treaties that Do Not Incorporate the Discretionary Relief Provision}

70. Moreover, it should be noted that only a few countries, which have adopted the PPT, have opted for the discretionary relief clause. ${ }^{169}$
Accordingly, another issue arises, with respect to the foregoing rule shopping or treaty shopping situations, as to what happens when a tax treaty does not contain a discretionary relief clause? One could argue that if the tax treaty does not contain such a clause then treaty benefits (the benefit of $15 \%$ in the rule shopping case and the benefit of $10 \%$ in the treaty shopping case) shall not be granted and hence the domestic withholding tax rates should apply. This argument should be rejected. The author submits that Article 7(4) does not represent a minimum standard. Accordingly, if this provision is not included in a tax treaty, it does not mean that treaty benefits should not be granted, especially if such benefits are available under domestic law mechanisms. ${ }^{170}$ With respect to transactions that can be considered to be abusive within the EU, the European Court of Justice (ECJ)in the Halifax case has ruled 'transactions involved in an abusive practice must be redefined so as to re-establish the situation that would have prevailed in the absence of the transactions constituting that abusive practice. ${ }^{171}$ Advocate General Bobek has expressed a similar position in the recent Cussens case. ${ }^{172}$ Therefore, the rule shopper $(\mathrm{Mr} \mathrm{X})$ or the treaty shopper (TCO) should be given access to the lower rates. ${ }^{173}$

\section{Key conclusions}

71. With respect to the PPT elements, the author, firstly, submits that benefits arising to a taxpayer under the domestic law (direct or indirect tax related benefits) or another tax treaty or EU Law will not fall under the scope of this test. Secondly, the author submits that the subjective element of the PPT shall be interpreted in a 'restrictive manner' in the sense that if the transaction or arrangement at stake has economic or commercial justifications

\section{Notes}

166 Danon \& Salome, MLI, s. 3.6.

167 Lang, PPT rule, at 662.

168 For a possible suggestion see Danon \& Salome, MLI, s. 3.6.

169 See the positions adopted by Andorra, Australia, Belgium, Costa Rica, Cyprus, Czech Republic, Fiji, Gabon, Guernsey, Hungary, Ireland, Isle of Man, Jersey, Liechtenstein, Lithuania, Luxembourg, Malta, Netherlands, New Zealand, Pakistan, San Marino, Senegal, Seychelles, Singapore, United Kingdom and Uruguay.

170 For instance, in Switzerland, treaty benefits are granted to re-characterized fact patterns. See Danon, Salome, MLI, s. 3.3.2.4 and s. 3.6. The US also seems to adopt a similar approach in conduit financing cases wherein the transactions are re-characterized. See US Treasury regulations, 1.881-3 (effect of income tax treaties). The HMRC seems to adopt a similar position in treaty shopping cases. See Examples 7 and 8 discussed in HMRC, Double taxation claims and applications - Beneficial ownership, INTM 332080.

171 ECJ: Halifax plc and others v. Customs and Excise Commissioners, Case No: C-255/02, 21 Feb. 2006, paras 93-94. Also see ECJ: Test Claimants in the Thin Cap Group Litigation v. Commissioners of Inland Revenue, Case No: C-524/04, 13 Mar. 2007, paras 80-83. In that case, the ECJ held that even if abuse arises, UK domestic thin capitalization rules should not adjust the profits of the borrower beyond that mandated by the arm's length standard.

172 Opinion of Advocate General Bobek, Cussens and others, Case No: C-251/16, 7 Sept. 2017, paras 111-112.

173 See De Broe, EU Law, at 239; Danon \& Salome, MLI, s. 3.6. 
other than obtaining a tax advantage, then this element is not fulfilled. Thirdly, with respect to the objective element, a two-stage analysis will be required to ascertain the object and purpose of the 'relevant provisions'. Under the first stage, the taxpayer has to determine the object and purpose of the 'relevant provisions' in light of the overall objectives pursued by the tax treaty (legal analysis). Thereafter, under the second stage, taxpayer will have to prove that the transaction/arrangement respects the object and purpose of the 'relevant provisions' at stake (application of the legal analysis to the facts at stake). Further, the PPT will be has to be interpreted in light of its legislative intent, background and the commentary.

72. With respect to the discretionary relief clause in Article 7(4), the references to the term 'person' should be deleted as that reference narrows the scope of applying the clause. Secondly, treaty benefits should be granted to the taxpayer automatically rather than subjecting it to seek relief under an administrative mechanism, which could end up being burdensome. Thus the clause should be redrafted to reflect that "Where a benefit is denied under the PPT, treaty benefits shall nevertheless be extended to the situation that would have existed in the absence of the abusive transaction or arrangement." This being said, if this provision is not included in a tax treaty, it does not mean that treaty benefits should not be granted, especially if such benefits are available under domestic law mechanisms.

73. On a separate note, interesting issues arise with respect to the interaction of the PPT with other treaty anti avoidance rules such as the inherent anti-abuse rule, existing treaty GAARs and SAARs (the LOB clause, beneficial ownership clause, holding period provisions introduced in Article 10 and Article 13 of the 2017 Draft OECD Model and so on). Likewise, interesting issues arise with respect to the interaction of the PPT with other domestic anti-avoidance rules such as judicial doctrines, statutory GAARs and SAARs (antitreaty shopping rules or anti-rule shopping rules). These issues will be discussed in a subsequent contribution by the author.

\section{RECOMMENDATIONS FOR INTERMEDIARY COMPANIES: MINIMUM SAFEGUARDS}

74. The PPT has arrived and it is here to stay. There is no doubt that its interpretation will create a lot of uncertainty ${ }^{174}$ and lead to disputes. In light of the plethora of disputes that could arise as a result of applying the PPT, taxpayers (multinational groups, ${ }^{175}$ investment funds, financial institutions and others) that use/deploy intermediary entities should resort to certain minimum safeguards. The subjective element of the PPT should not be satisfied if the transaction or arrangement contains several non-tax reasons. In light of the foregoing examples (see section 4), an intermediary entity, at a minimum, should: (1) outline the commercial reasons for which it is set up; (2) provide non-tax reasons for being located in a particular jurisdiction; (3) ensure that a majority of the entities board of directors comprise of qualified local tax residents; (4) ensure that the board meets regularly and plays an active role in overseeing the activities of intermediary entity; (5) the day-day 'core' functions of the entity are carried out by the board and/or to the extent required by local specialist staff; (6) ensure that the entities personnel (board and/or operating staff) 'control' and have the 'financial capacity' to bear the risks associated with that entities investment or activities ${ }^{176}$; (7) demonstrate that it has the right to use and enjoy the income it receives and; (8) the entity owns/leases the necessary equipment and/or office space to carry out its activities. Specifically, with respect to holding companies, the personnel clearly demonstrate that they carry out shareholder related functions ${ }^{177}$ and take the necessary steps to manage and mitigate 'shareholder' related risks. Likewise, for financing companies, the personnel clearly demonstrate that they carry out financing related functions ${ }^{178}$ and take the necessary steps to manage and mitigate 'financial' related risks. ${ }^{179}$ Similarly for intellectual property entities, the personnel clearly demonstrate that they carry out development, enhancement, maintenance, protection and exploitation (DEMPE) related functions (till the extent relevant) and take the necessary steps to

\section{Notes}

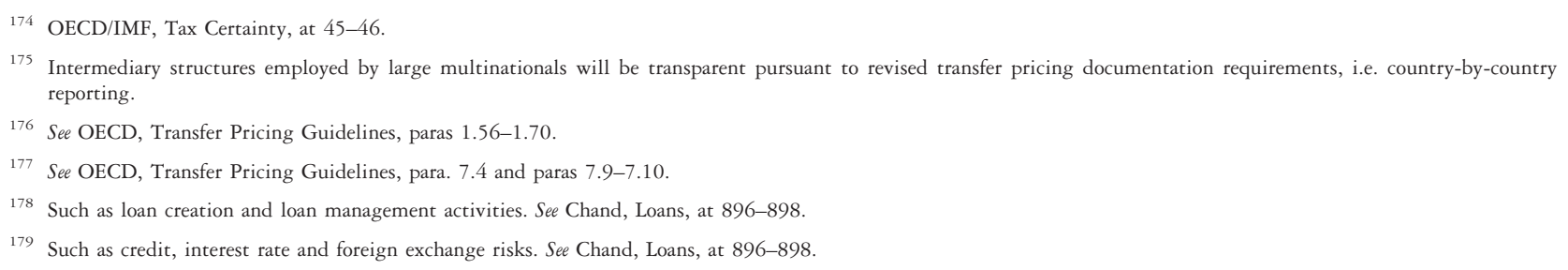


manage and mitigate the associated risks. ${ }^{180}$ Appropriate documentation to demonstrate the foregoing needs to be maintained on a robust basis. This being said, whether or not the PPT applies would depend on the precise facts and circumstances of each case.

\section{Biblography}

OECD related documents

OECD, Model Tax Convention on Income and Capital (1992) (Model text quoted as 1992 OECD Model and Model commentary (quoted as 1992 OECD Comm).

OECD, Model Tax Convention on Income and Capital: Condensed Version 2003 (OECD Publishing 2003), as read on 28 Jan. 2003 (Model text quoted as 2003 OECD Model and Model commentary (quoted as 2003 OECD Comm).

OECD, Model Tax Convention on Income and Capital: Condensed Version 2014 (OECD Publishing 15 July 2014) (Model text quoted as 2014 Model and Model Commentary (quoted as 2014 OECD Comm).

OECD/G20, Preventing the Granting of Treaty Benefits in Inappropriate Circumstances, OECD/G20 Base Erosion and Profit Shifting Project (OECD Publishing 16 Sept. 2014) (quoted 2014 OECD, Report on Treaty Abuse).

OECD, Follow Up Work on BEPS Action 6: Preventing Treaty Abuse, Public Discussion Draft (21 Nov. 2014) (quoted OECD Follow up work on BEPS Action 6).

OECD/G20, Making Dispute Resolution Mechanisms More Effective, OECD/G20 Base Erosion and Profit Shifting Project (OECD Publishing 5 Oct. 2015) (quoted 2015 OECD, Final Report on Dispute Resolution).

OECD/G20, Preventing the Artificial Avoidance of Permanent Establishment Status, OECD/G20 Base Erosion and Profit Shifting Project (OECD Publishing 5 Oct. 2015) (quoted 2015 OECD, Final Report on Permanent Establishments).

OECD/G20, Preventing the Granting of Treaty Benefits in Inappropriate Circumstances, OECD/G20 Base Erosion and Profit Shifting Project (OECD Publishing 5 Oct. 2015) (quoted 2015 OECD, Final Report on Treaty Abuse).

OECD/G20, Neutralizing the Effects of Hybrid Mismatch Arrangements, OECD/G20 Base Erosion and Profit Shifting Project (OECD Publishing 5 Oct. 2015) (quoted 2015 OECD, Final Report on Hybrid Mismatches).
OECD/G20, Multilateral Convention to Implement Tax Treaty Related Measures to Prevent Base Erosion and Profit Shifting (24 Nov. 2016) (quoted 2016 OECD, Multilateral Convention).

OECD/G20, Explanatory Statement to the Multilateral Convention to Implement Tax Treaty Related Measures to Prevent Base Erosion and Profit Shifting (24 Nov. 2016) (quoted 2016 OECD, Explanatory Statement to the Multilateral Convention).

OECD/IMF, Tax Certainty, Report for the G20 Finance Ministers (Mar. 2017).

OECD, BEPS Action 6 Discussion Draft on Non-CIV Examples (6 Jan. 2017) (quoted as 2017 OECD, Discussion Draft on Non-CIV Examples).

OECD, Model Tax Convention on Income and Capital: Condensed Version 2017, Draft, (OECD Publishing 11 July 2017) (Model text quoted as 2017 Model Draft and Model Commentary quoted as 2017 OECD Comm (Draft)).

EU and UN related documents

European Commission, Implementation of Measures Against Tax Treaty Abuse 1-4 (2016) (quoted European Commission, Recommendation on Treaty Abuse).

European Council Directive 2016/1164, Laying Down Rules Against Tax Avoidance Practices that Directly Affect the Functioning of the Internal Market (2016) (quoted EU ATAD, Directive 2016/1164).

European Council Directive 2015/121 (2015) (quoted EU PSD, Directive 2015/121).

European Council Directive 90/434/EEC (1990) MD (quoted Directive 90/434/EEC).

UN, Model Double Tax Convention Between Developed and Developing Countries (2011) (Model text quoted as 2011 UN Model and Model commentary quoted as 2011 UN Comm).

Books and Articles

Brian J. Arnold, The Concept of Beneficial Ownership Under Canadian Tax Treaties, in Beneficial Ownership: Recent Trends 39-48 (Lang, Pistone, Schuch, Staringer, \& Storck eds, Amsterdam 2006) (quoted Arnold, Beneficial Ownership).

Brian J. Arnold, Tax Treaties and Tax Avoidance: The 2003 Revisions to the Commentary on the OECD Model, 58(6) Bull. Tax Treaty Monitor 244-260 (2004) (quoted Arnold, 2003 changes).

Brian J. Arnold \& Stef Van Weeghel, The Relationship Between Tax Treaties and Domestic Anti-Abuse Measures, in Tax Treaties and Domestic Law, EC and International Tax

\section{Notes}

180 See OECD, Transfer Pricing Guidelines, paras 6.47-6.72. 
Law Series, vol. 2, 81-120 (Maisto ed., Amsterdam, IBFD 2006) (quoted Arnold \& Van Weeghel, Abuse).

Philip Baker, The Multilateral Convention to Implement Tax Treaty Related Measures to Prevent Base Erosion and Profit Shifting, Brit. Tax Rev. 281 (2017) (quoted: Baker, MLI).

Beaulne \& Angelo Nikolakakis, The Untbinkable Anathema of Double Non-Taxation: The Relevance and Implications of Foreign Tax Considerations in the Context of Applying GAAR, 58, Special Supplement Can. Tax J. 243-301 (2010) (quoted Beaulne \& Nikolakakis, Double non taxation).

Yariv Brauner, Beneficial 'Ownership in and Outside US Tax Treaties', in Beneficial Ownership: Recent Trends 143160 (Lang, Pistone, Schuch, Staringer, \& Storck eds, Amsterdam 2013) (quoted Brauner, Beneficial Ownership).

Alexander Bosman, General Aspects of the Multilateral Instrument, 45(10) Intertax 642-659 (2017) (quoted Bosman, MLI).

Jakob Bundgaard, The Notion of Beneficial Ownership in Danish Tax Law: The Creation of a New Legal Order with Uncertainty as a Companion, in Beneficial Ownership: Recent Trends 91-117 (Lang, Pistone, Schuch, Staringer, \& Storck eds, Amsterdam 2006) (quoted Bundgaard, Beneficial Ownership).

Mukesh Butani, The Multilateral Instrument Era: Measuring the Impact on India, Asia-Pac. Tax Bull. 1 (2017), (quoted Butani, MLI).

Vikram Chand, The Interaction of Domestic Anti-Avoidance Rules with Tax Treaties (Zürich: Schulthess 2017 forthcoming) (quoted Chand, Thesis).

Vikram Chand, Transfer Pricing Aspects of Intra - Group Loans in Light of the Base Erosion and Profit Shifting Action Plan, 44(12) Intertax 885-902 (2016) (quoted Chand, Loans).

Vikram Chand, Transfer Pricing Aspects of Cash Pooling Arrangements in Light of the BEPS Action Plan, Int'l Transfer Pricing J. (2016) (quoted Chand, Cash Pooling).

Robert Danon \& Hugues Salome, The BEPS Multilateral Instrument, in IFF Forum Für Steuerrecht 197247 (2017) (quoted Danon \& Salome, MLI).

Ana Paula Dourado, Aggressive Tax Planning in EU Law and in Light of BEPS: The EC Recommendation on Aggressive Tax Planning and BEPS Action 2 and 6, 43(1) Intertax 4257 (2015) (quoted Dourado, Abuse).

Luc De Broe, Tax Treaty and the EU Law Aspects of the LOB and PPT Provision Proposed by BEPS Action 6, in Base Erosion and Profit Shifting (BEPS): Impact for European and International Tax Policy 197-252 (Amsterdam 2016) (quoted De Broe, EU Law).

Luc De Broe \& Joris Luts, BEPS Action 6: Tax Treaty Abuse, 43(2) Intertax 122-146 (2015) (quoted De Broe \& Luts, BEPS).
Luc De Broe, International Tax Planning and Prevention of Abuse vol. 14 - Doctoral Series (Amsterdam: IBFD 2008) (quoted De Broe, Thesis).

Frank Engelen, Interpretation of Tax Treaties Under International Law: A Study of Articles 31, 32, and 33 of the Vienna Convention on the Law of Treaties and Their Application to Tax Treaties (Amsterdam 2004) (quoted Engelen, thesis).

Daniel Gutmann, Beneficial Ownership as Anti-Abuse Provision: The Bank of Scotland Case, in Beneficial Ownership: Recent Trends 167-172 (Lang, Pistone, Schuch, Staringer, \& Storck eds, Amsterdam 2013) (quoted Gutmann, Beneficial Ownership).

Johann Hattingh, The Multilateral Instrument From a Legal Perspective: What May Be The Challenge?, Bull. Int'l Tax'n 1 (2017) (quoted: Hattingh, MLI).

Adolfo Jimenez, Beneficial Ownership as a Broad AntiAvoidance Provision: Decisions by Spanish Courts and the OECD's Discussion Draft, in Beneficial Ownership: Recent Trends (Lang, Pistone, Schuch, Staringer, \& Storck eds, Amsterdam 2013) 127-141 (quoted Jimenez, Beneficial Ownership).

Reinout Kok, The Principal Purpose Test in Tax Treaties Under BEPS 6, 44(5) Intertax 406-412 (2016) (quoted Kok, PPT).

Michael Lang, BEPS Action 6: Introducing an Anti Abuse Rule in Tax Treaties, Tax Notes Int'l 655-664 (19 May 2014) (Lang, PPT rule).

Michael Lang, General Report vol. 89a, in Double NonTaxation, IFA, Cahiers de Droit Fiscal International 74-119 (2004) (quoted Lang, Double non taxation).

Andrés Moreno, GAARs and Treaties: From the Guiding Principle to the Principal Purpose Test. What Have We Gained from BEPS Action 6?, (6/7) Intertax 432-446 (2017) (quoted Moreno, PPT).

Angelika Ringler, Beneficial Ownership in International Tax Law (Alphen aan den Rijn 2016) (quoted Ringler, Beneficial Ownership).

Daniël Smit, The Concept of Beneficial Ownership and Possible Alternative Remedies in Netherlands Case Law, in Beneficial Ownership: Recent Trends 59-89 (Lang, Pistone, Schuch, Staringer, \& Storck eds, Amsterdam 2013) (quoted Smit, Beneficial Ownership).

Stef Van Weeghel, The Improper Use of Tax Treaties (Kluwer Law International, London 1998) (quoted Van Weeghel, Thesis).

Klaus Vogel \& Rainer Prokisch, General Report vol. 78a, in Interpretation of Double Tax Conventions 55-85 (IFA Cahiers de Droit Fiscal International 1993) (quoted Vogel \& Prokisch, Interpretation).

Klaus Vogel, Klaus Vogel on Double Taxation Conventions (1997) (quoted Vogel, Commentary).

Dennis Weber, The Reasonableness Test of the Principal Purpose Test Rule in the OECD BEPS Action 6 (Tax Treaty Abuse) versus the EU Principle of Legal Certainty and the EU Abuse of Law Case Law, 10(1) Erasmus L. Rev. (28 Aug. 2017) (quoted WEBER, PPT). 


\section{International Case Law}

European Court of Justice

Emsland-Stärke GmbH v. Hauptzollamt Hamburg-Jonas, Case No: C-110/99, 14 Dec. 2000.

Halifax plc and others v. Customs and Excise Commissioners,

Case No: C-255/02, 21 Feb. 2006.

Cadbury Schweppes plc and Cadbury Schweppes Overseas Ltd

v. Commissioners of Inland Revenue, Case No: C-196/04, 12

Sept. 2006.

Hans Markus Kofoed v. Skatteministeriet, Case No: C-321/ 05, 5 July 2007.

Sociedade Gestora de Participações Sociais SA v. Secretário de Estado dos Assuntos Fiscais, Case No: C-126/10, 10 Nov. 2011.

Opinion of Advocate General Bobek in Cussens and others, Case No: C-251/16, 7 Sept. 2017.

\section{Australia}

Federal Court of Australia in FC of T. v. Lamesa Holdings BV, 97 ATV 4752, 20 Aug. 1997.

\section{Canada}

Canadian Supreme Court: Canada Trust Co Mortgage Co v.

Canada, 8 ITLR 276, 19 Oct. 2005.

Canadian Tax Court: MIL (Investments) SA v. Canada, 9 ITLR 25, 18 Aug. 2006.

Canadian Tax Court: Garron and another v. R; Re Garron Family Trust; Garron v. R; St Michael Trust Corp v. R; Re Fundy Settlement; Dunin v. R; St Michael Trust Corp v. R; Re Summers by Settlement, 12 ITLR 79, 10 Sept. 2009.
Canadian Tax Court: Antle v. R; Marquis-Antle Spousal Trust v. R; ANtle and another v. R, 12 ITLR 359, 18 Sept. 2009.

France

French Supreme Court: Ministre de l'Economie, des Finances et de l'Industrie v. Société Bank of Scotland, 9 ITLR 683, 29 Dec. 2006.

\section{United States}

US Tax Court: Aiken Industries, Inc v. Commissioner of Internal Revenue, 56 TC 925, 5 Aug. 1971.

US Court of Appeals: Northern Indiana Public Service Company v. Commissioner, 115 F3d 506, 6 June.

\section{Switzerland}

Swiss Supreme Court: A Holding ApS v. Federal Tax Administration, 8 ITLR 536, 28 Nov. 2005, at 536-562.

Others

UK-Swiss Tax Treaty (1977 as amended by the 2009 protocol).

US Internal Revenue Code, 1986 (quoted US IRC) and US Treasury regulations.

US-UK Tax Treaty (2001) and Exchange of letters on the interpretation of the UK-US tax treaty, 19 July 2002.

HMRC, Double taxation claims and applications - Beneficial ownership, INTM 332080.

HMRC, Double Taxation applications and claims: Applicants/claimants, INTM 338000.

HMRC, Double taxation claims and applications - Beneficial ownership, INTM 332080. 